\title{
An Experimental Research Study on the Solution of a Private Small Hydropower Plant Investments Selection Problem by ELECTRE III/IV, Shannon's Entropy, and Saaty's Subjective Criteria Weighting
}

\author{
Burak Omer Saracoglu ${ }^{1,2}$ \\ ${ }^{1}$ Institute of Science \& Technology, Istanbul Technical University, 34469 Istanbul, Turkey \\ ${ }^{2}$ Faculty of Naval Architecture \& Ocean Engineering, Istanbul Technical University, 34469 Istanbul, Turkey \\ Correspondence should be addressed to Burak Omer Saracoglu; burakomersaracoglu@hotmail.com
}

Received 23 August 2014; Revised 18 November 2014; Accepted 20 December 2014

Academic Editor: Roger Z. Ríos-Mercado

Copyright (C) 2015 Burak Omer Saracoglu. This is an open access article distributed under the Creative Commons Attribution License, which permits unrestricted use, distribution, and reproduction in any medium, provided the original work is properly cited.

\begin{abstract}
Almost all of the today's modern daily life conditions of humankind depend on the electricity. The countries either by only themselves or sometimes with some international intuitions and/or organizations have been trying to find the best methods, ways, and projects to supply the electricity to their societies. One of the important tools for the countries to increase the amount and quality of the electricity generation is to activate/ignite/initiate the private investment capabilities/opportunities. The electricity generation market in Turkey is a free/open market for both the foreign and domestic private investors. Hence, both the foreign and domestic private investors have been looking for the most suitable electricity generation plant projects. Small hydropower plant (SHPP) investments (SHPPIs) are one of the alternatives in the Turkish electricity generation market especially for the private investors searching for the renewable energy investments. This experimental research study investigates the possibility of using the ELECTRE III/IV, Shannon's Entropy, and Saaty's Analytic Hierarchy Process (AHP) subjective weighting (for criteria) methods for the solution of this problem. In the experimental case study, the most appropriate SHPPIs amongst five alternative SHPPIs at the SHPPIs' predevelopment investment stages in Turkey were evaluated and ranked in order.
\end{abstract}

\section{Introduction}

The peak load and the electricity consumption in Turkey have been increasing in almost steady conditions since 1996 as presented in Table 1. The causes of this almost steady electricity demand increase condition are mainly given as the increase in the population in Turkey and the increase in the income growth in Turkey by the researchers (see and read some studies on this issue [1-3]).

These increasing conditions of the population and the gross domestic product (GDP) in Turkey are presented by the help of the historical data as shown in Figure 1 for expressing and showing the actual situation of these conditions very clearly and plainly to the researchers, the academics, the private investors, and the whole readers.
In addition to these historical data, several projection studies for these two indicators present that the growth status will continue in the long term (see and read some studies on this issue [1-3]).

The location of Turkey is very interesting and strategic in the point of view of the geographical, geopolitical, and socioeconomic research studies (see and read [4-6]). Turkey is a transcontinental (Europe and Asia) country that has the land boundaries with Syria $(822 \mathrm{~km})$ (southeast), Iran $(499 \mathrm{~km})$ (east), Iraq $(352 \mathrm{~km})$ (southeast), Armenia $(268 \mathrm{~km})$ (east), Georgia $(252 \mathrm{~km})$ (northeast), Bulgaria $(240 \mathrm{~km})$ (northwest), Greece $(206 \mathrm{~km})$ (west), and Azerbaijan $(9 \mathrm{~km})$ (east) (see and read [7]). Turkey can be grouped under several geographical and socioeconomic regions such as the Balkans (Bulgaria, Greece, etc.) (see and read [8]), the Caucasus 
TABLE 1: The peak load and the electricity consumption of Turkish Interconnected Electricity System.

\begin{tabular}{lcccc}
\hline Year & Peak load (MW) & Percent change $(\%)$ & Electricity consumption $(\mathrm{GWh})$ & Percent change $(\%)$ \\
\hline 1996 & 15.231 & 7.5 & 94.789 & 10.8 \\
1997 & 16.926 & 11.1 & 105.517 & 11.3 \\
1998 & 17.799 & 5.2 & 114.023 & 8.1 \\
1999 & 18.938 & 6.4 & 128.276 & 3.9 \\
2000 & 19.390 & 2.4 & 126.871 & 8.3 \\
2001 & 19.612 & 1.1 & 132.553 & -1.1 \\
2002 & 21.006 & 7.1 & 141.151 & 4.5 \\
2003 & 21.729 & 3.4 & 150.018 & 6.5 \\
2004 & 23.485 & 8.1 & 160.806 & 6.3 \\
2005 & 25.174 & 7.2 & 174.637 & 7.2 \\
2006 & 27.594 & 9.6 & 190.000 & 8.6 \\
2007 & 29.249 & 6.0 & 198.085 & 8.8 \\
2008 & 30.517 & 4.3 & 194.079 & 4.3 \\
2009 & 29.870 & -2.1 & 210.434 & -2.0 \\
2010 & 33.392 & 11.8 & 229.319 & 8.4 \\
\hline
\end{tabular}

Data and source $[14,15]$.

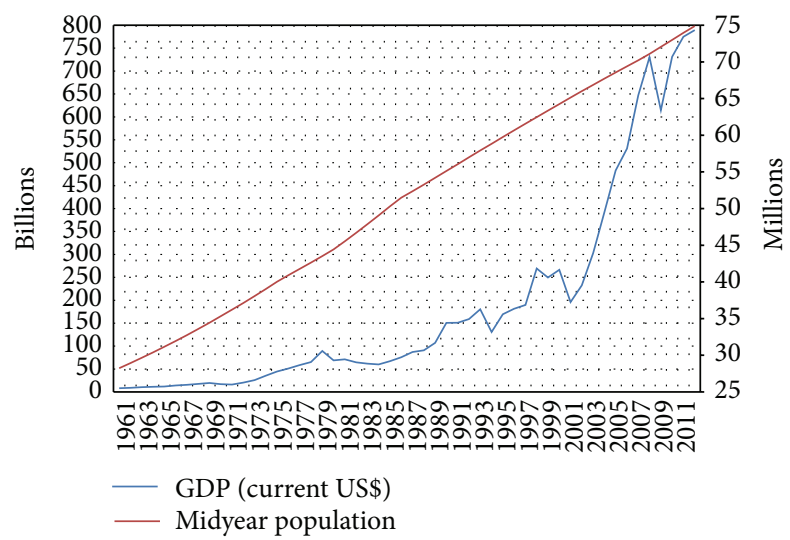

FIGURE 1: GDP: gross domestic product and population in Turkey (generated by the Microsoft Office Excel 2007). Data: GDP (current USD, 1961-2012) [12] (left axis), midyear population estimations (1961-2012) [13] (right axis).

Region (Azerbaijan, Georgia, etc.) (see and read [9]), the Europe (France, Germany, etc.) (see and read [10]), and the MENA Region (Middle East and North Africa: Egypt, Morocco, etc.) (see and read [11]). This geographical location also gives an advantage to Turkey to interconnect its national electricity grid to the other national electricity grids, which also increases very much the importance of the current subject of this experimental research study, not only for the perspective of Turkey, but also for the perspective of the regions, such as the Balkans, the Caucasus, and the MENA.

The Turkish electricity generation establishments can be grouped according to their management styles, organization structures, sizes, and business capabilities. The diversified characteristics and properties of these entities in the Turkish electricity generation market make the business and management models and organizations classification study not so difficult. The decision making process of these entities are different from each other based on these characteristic differences. The application and adaptation of several appropriate scientific methods are very important for some entities, so that the more the research studies by the different approaches and methods are conducted in this subject, the more the appropriate scientific methods and approaches will be started to be used and preferred in the decision making process of the private small hydropower plant investments (PSHPPIs) in the practical daily life, which will expectedly increase the total satisfaction on the PSHPPIs of all of the participants, the parties, and the involvers.

The entities or the investors in the Turkish electricity generation sector can either invest in the renewable energy sources (RESs) main group or in the fossil fuels sources main group. The hydropower and the wind power in the RESs main group and the natural gas and the imported coal in the fossil fuels main group have the major pie or share groups in this market. The projected installed capacity by the primary energy resources is presented in Figure 2.

The hydropower plants are grouped as one segment without considering their installed capacities (each power plant) in this projection. Figure 2 shows that the total percentage or share of the installed capacity of the hydropower plants in Turkey shall be increased or tried to be increased to almost $40 \%$ of the total installed power of the whole power plants in Turkey until 2020s, which indicates and means that the subject of this experimental research study will keep its importance in the short to long terms and periods. Generally, the hydropower plants are classified based on their installed capacities $(P)$ as large, medium, small, mini-, micro-, and picohydropower plants. However, the consensus on the installed capacities of this classification has not been achieved yet. For instance, the SHPP installed capacity $(\mathrm{kW})$ was presented as $(P<10.000)$ by Dragu et al. [33], $(P<10.000)$ by EREC [34], (1.000<P 10.000) by ESHA [35], 


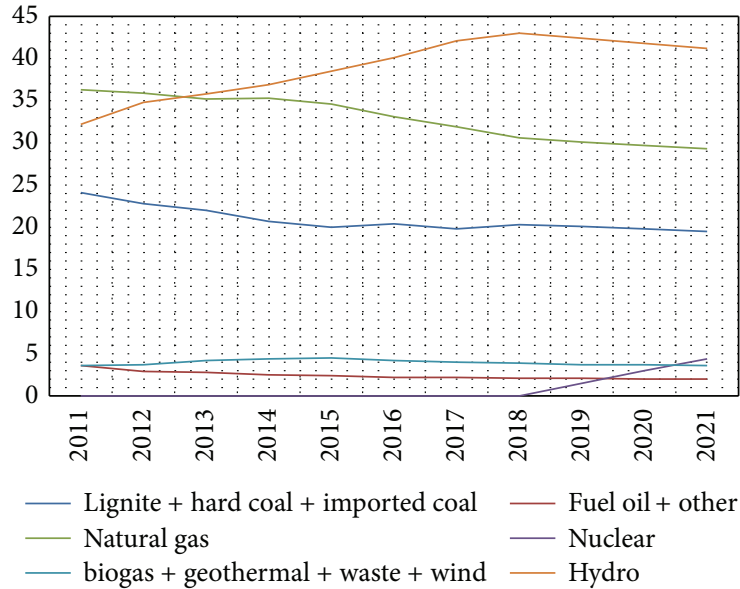

FIGURE 2: Projected installed capacity (average of scenarios 1 and 2 ) in Turkey (\% of MW) (generated by the Microsoft Office Excel 2007). Data: $[14,15]$.

$(2.000<P \leq 25.000)$ by Mishra et al. [36], and $(3.000<$ $P \leq 25.000$ ) by Ramachandra and Shruthi [37].

In the current study, the SHPPs were accepted as the hydropower plants that had the installed capacity of $1.000 \mathrm{~kW}<P \leq 10.000 \mathrm{~kW}$. The EMRA's (Republic of Turkey Energy Market Regulatory Authority) official website (http://www.emra.gov.tr/ or http://www.epdk.gov.tr/) had been visited several times before this experimental research study was started. There were 212 SHPPs with the total installed electrical power of 1.048 MWe until September 2012 under the investigation and evaluation stage of the license application procedure (see Figure 3 for the SHPPs' applications to EMRA cumulative by year). The foreign, domestic, and local private investors (foreign: investors from all over the world such as Austria, Norway, and England; domestic: investors from Turkey; local: investors from Artvin) were able to investigate, select, invest, and have in their SHPPI portfolio (some of the megawatts) from the PSHPPI alternatives as shown in Figure 3.

The presented data and the socioeconomic conditions prove and show the reasons, why the investors have searched for the private SHPP investments (PSHPPIs) as the long term real sector investment alternatives. Small to large size private investors (establishments or real people) with different strategic investment plans have tried to find the PSHPPIs for having some or whole of the shares. Some of the investors have also looked for several numbers of PSHPPIs to have them as one group.

In this respect, the main objective and the main problem of the private investors that should be solved in the most appropriate, convenient, simple, and understandable ways (please keep in mind that there may be several ways, not only one way) for the private investors are to find and select the most satisfying PSHPPIs on the point of view of the private investors' (in a more scientifically clear clause or statement: the decision makers of the private investors or the private investors by themselves) understanding, perception, and character amongst the possible alternative PSHPPIs. For

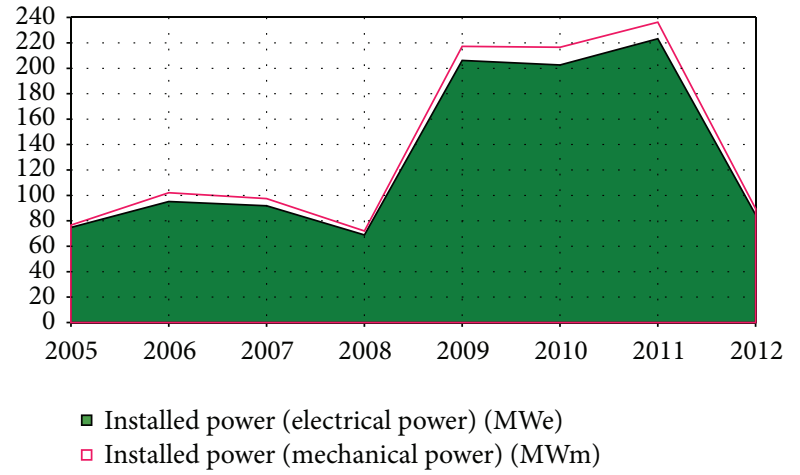

FIgure 3: SHPPs' applications to EMRA (Latest 2012 September) (generated by the Microsoft Office Excel 2007). Data: [14] (only official website).

instance, the intentions of the different private investors (a private investor may be an institutional investor, a legal entity, a national or international joint venture, and a single natural person or a group of them) are very different from each other (for instance, the net profit maximization in the short term or the risk minimization in the long term) that makes them to take into account and consideration very different factors during the solution of the finding and selection problem of the PSHPPIs. The main aim of this study is to contribute to the scientific studies by defining the PSHPPIs' selection problem and presenting an experimental research for its solutions.

In this paper, a private SHPPs' investment selection problem in Turkey was solved by mainly help of the ELECTRE (Elimination and Choice Translating Reality: Elimination Et Choix Tradusiant la Realite) methods (one of the Multicriteria Decision Making (MCDM) methods). The objective and subjective weighting methods were adopted for the decision of the criteria weights or the voting power of the factors only. In the current experimental research case study, there were five private SHPP alternative investments (PSHPPIs), which the titles were not presented, because of the possibility of the continuity of their commercially sensitive situations, in Turkey. However, the sufficient data and information were presented for the readers to make them understand the experimental research case very well.

This paper consists of four sections. The methods are presented by the literature review in the next section. The experimental research case study is explained and the experimental research case study results are given in the third section. Finally, the conclusions and future research are discussed and presented in Section 4.

\section{Materials and Methods}

The previous studies in the literature were reviewed in the explicated twofold framework as presented in Figure 4.

The previous studies in the first fold framework were reviewed on some scientific online database websites (all fields' option selected) by help of the selected keywords until the 1st of January in 2014. The literature review in the first 


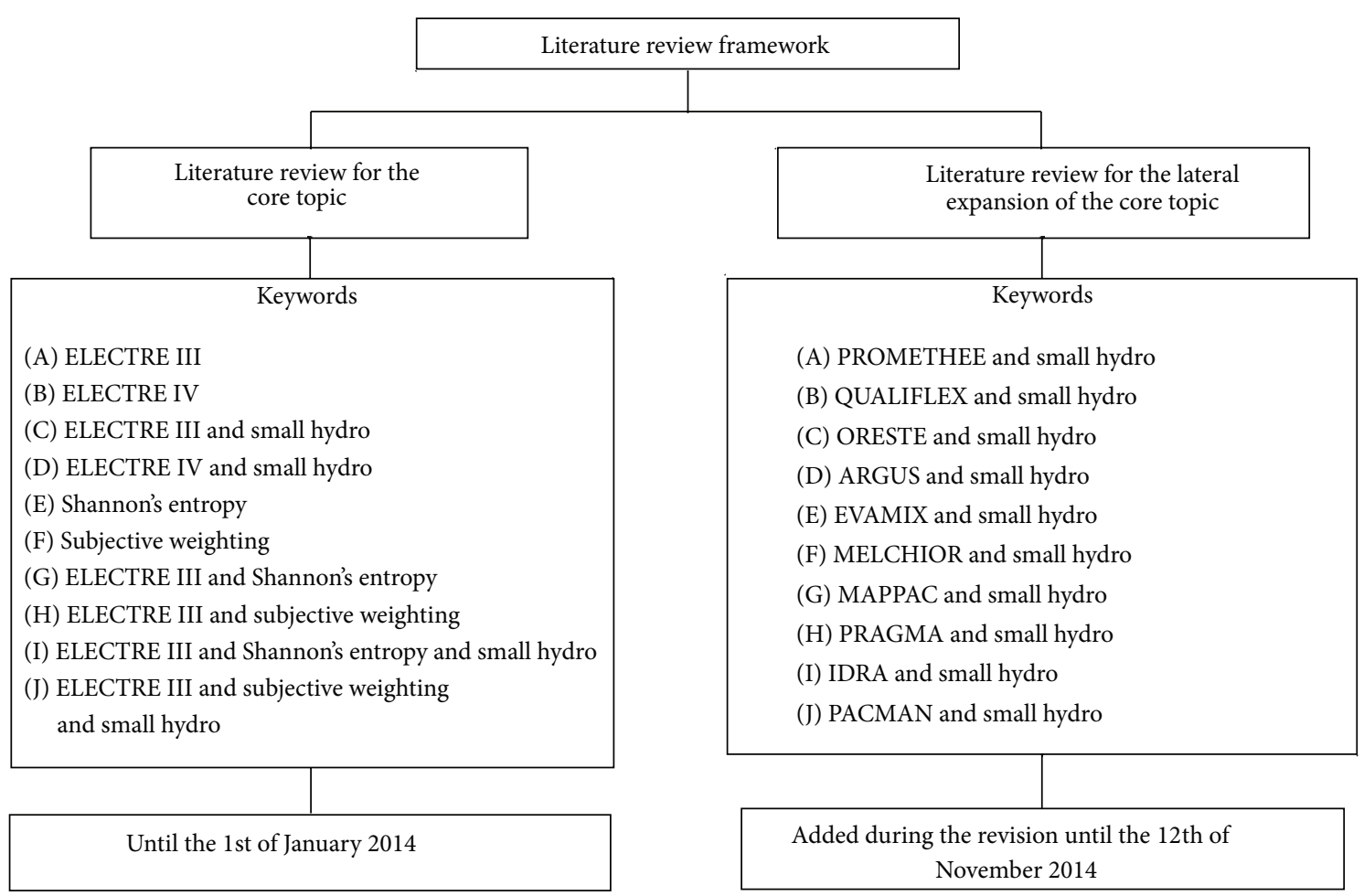

FIGURE 4: The literature review framework of the current experimental research study (generated by the Apache OpenOffice 4.1.0 Draw).

TABLE 2: Summary of the literature review in the first fold framework.

\begin{tabular}{|c|c|c|c|c|c|c|c|c|c|c|}
\hline \multirow{2}{*}{ Scientific publisher } & \multicolumn{10}{|c|}{ Key terms } \\
\hline & (A) & (B) & (C) & (D) & $(\mathrm{E})$ & $(\mathrm{F})$ & (G) & (H) & (I) & $(\mathrm{J})$ \\
\hline ACMDL & 112 & 16 & 0 & 0 & 630 & 53 & 1 & 1 & 0 & 0 \\
\hline ASCEOR & 17 & 1 & 0 & 0 & 30 & 35 & 0 & 0 & 0 & 0 \\
\hline ASME & 2 & 0 & 0 & 0 & 25 & 3 & 0 & 0 & 0 & 0 \\
\hline CJO & 3 & 0 & 0 & 0 & 35 & 35 & 0 & 0 & 0 & 0 \\
\hline DOAJ & 21 & 6 & 0 & 0 & 11 & 1 & 0 & 0 & 0 & 0 \\
\hline EI & 6 & 0 & 0 & 0 & 7 & 10 & 0 & 0 & 0 & 0 \\
\hline SD & 416 & 69 & $8^{*}$ & 0 & 1.156 & 448 & 2 & 10 & 0 & 0 \\
\hline TFJ & 84 & 21 & $1^{*}$ & 0 & 2 & 116 & 0 & 1 & 0 & 0 \\
\hline WB & 75 & 18 & 0 & 0 & 329 & 456 & 1 & 0 & 0 & 0 \\
\hline WSP & 14 & 5 & 0 & 0 & 175 & 12 & 0 & 11 & 0 & 0 \\
\hline
\end{tabular}

Data and source: ACM Digital Library (ACMDL) (http://dl.acm.org/), ASCE Online Research Library (ASCEOR) (http://ascelibrary.org/), ASME (http://asmedigitalcollection.asme.org/), Cambridge Journals Online (CJO) (http://journals.cambridge.org/), DOAJ (http://doaj.org/), Emerald Insight (EI) (http://www.emeraldinsight.com/), Science Direct (SD) (http://www.sciencedirect.com/), Taylor \& Francis Journal (TFJ) (http://www.tandfonline.com/), Wiley-Blackwell (WB) (http://onlinelibrary.wiley.com/), and World Scientific Publishing (WSP) (http://www.worldscientific.com/).

Keywords: (A): ELECTRE III, (B): ELECTRE IV, (C): ELECTRE III and small hydro* (aim and scope difference with the current study), (D): ELECTRE IV and small hydro, (E): Shannon's entropy, (F): subjective weighting, (G): ELECTRE III and Shannon's entropy, (H): ELECTRE III and subjective weighting, (I): ELECTRE III and Shannon's entropy and small hydro, and (J): ELECTRE III and subjective weighting and small hydro.

fold framework showed that this paper would most probably be one of the first studies in its aim and scope (see Table 2).

The previous studies in the second fold framework were reviewed on the same scientific online database websites with the same search options by help of the new selected keywords until the 12th of November in 2014. The keywords or key phrases included the set of the other outranking methods such as the PROMETHEE (Preference Ranking
Organization METHod for Enrichment Evaluations), the QUALIFLEX (QUALItative FLEXible), the ORESTE (Organization, Rangement Et Synthese De Donnes Relationnelles), the ARGUS (Achieving Respect for Grades by Using ordinal Scales), the EVAMIX (Evaluation of Mixed Criteria), the MELCHIOR (Méthode d'ELimination et de Choix Incluant les relation d'ORdre), the MAPPAC (Multicriterion Analysis of Preferences by Means of Pairwise Actions and Criterion 
TABLE 3: Summary of the literature review in the second fold framework.

\begin{tabular}{|c|c|c|c|c|c|c|c|c|c|c|}
\hline \multirow{2}{*}{ Scientific publisher } & \multicolumn{10}{|c|}{ Key terms } \\
\hline & (A) & (B) & (C) & (D) & (E) & (F) & (G) & $(\mathrm{H})$ & (I) & $(\mathrm{J})$ \\
\hline ACMDL & 0 & 0 & 0 & 0 & 0 & 0 & 0 & 0 & 0 & 0 \\
\hline ASCEOR & 0 & 0 & 0 & 0 & 0 & 0 & 0 & 0 & 0 & 0 \\
\hline ASME & 0 & 0 & 0 & 0 & 0 & 0 & 0 & 0 & 0 & 0 \\
\hline CJO & 0 & 0 & 0 & 0 & 0 & 0 & 0 & 0 & 0 & 0 \\
\hline DOAJ & 0 & 0 & 0 & 0 & 0 & 0 & 0 & 0 & 0 & 0 \\
\hline EI & 0 & 0 & 0 & 0 & 0 & 0 & 0 & 0 & 0 & 0 \\
\hline SD & $21^{*}$ & 0 & $2^{*}$ & $15^{*}$ & 0 & $3^{*}$ & 0 & $2^{*}$ & 0 & 0 \\
\hline TFJ & $1^{*}$ & 0 & 0 & $1^{*}$ & 0 & $1^{*}$ & 0 & 0 & 0 & 0 \\
\hline WB & $1^{*}$ & 0 & $1^{*}$ & 0 & 0 & 0 & 0 & 0 & 0 & 0 \\
\hline WSP & 0 & 0 & 0 & 0 & 0 & 0 & 0 & 0 & 0 & 0 \\
\hline
\end{tabular}

Data and source: ACM Digital Library (ACMDL) (http://dl.acm.org/), ASCE Online Research Library (ASCEOR) (http://ascelibrary.org/), ASME (http://asmedigitalcollection.asme.org/), Cambridge Journals Online (CJO) (http://journals.cambridge.org/), DOAJ (http://doaj.org/), Emerald Insight (EI) (http://www.emeraldinsight.com/), Science Direct (SD) (http://www.sciencedirect.com/), Taylor \& Francis Journal (TFJ) (http://www.tandfonline.com/), Wiley-Blackwell (WB) (http://onlinelibrary.wiley.com/), and World Scientific Publishing (WSP) (http://www.worldscientific.com/).

Keywords: (A): PROMETHEE and small hydro* (aim and scope difference with the current study), (B): QUALIFLEX and small hydro, (C): ORESTE and small hydro* (aim and scope difference with the current study), (D): ARGUS and small hydro* (aim and scope difference with the current study), (E): EVAMIX and small hydro, (F): MELCHIOR and small hydro* (aim and scope difference with the current study), (G): MAPPAC and small hydro, (H): PRAGMA and small hydro* (aim and scope difference with the current study), (I): IDRA and small hydro, and (J): PACMAN and small hydro.

Comparisons), the PRAGMA (Preference RAnking Global frequencies in Multicriteria Analysis), the IDRA (Intercriteria Decision Rule Approach), and the PACMAN (Passive and Active Compensability Multicriteria Analysis) (see the outranking methods in [38]). The literature review in the second fold framework presented that this paper would most probably be one of the first studies in the usage and application of the outranking methods for solving the problem explained in this study (see Table 3), which ought to have encourage to work on these presented outranking methods in Table 3 in the future research studies.

The first ELECTRE (ELimination Et Choix Traduisant la REalité: ELimination and Choice Expressing the REality) method (ELECTRE I: electre one), which was founded on the outranking approach (the European school approach), was proposed in the 1960s by Bernard Roy (the inventor of the family of ELECTRE methods) (1934-alive by November 2014), who was the founder of the LAMSADE and the researchers at the European consultancy company SEMA (Société d'Économie et de Mathématiques Appliquées) (British and French information technology merger) (see also LAMSADE (Laboratoire d'Analyse et Modélisation de Systèmes pour l'Aide à la DEcision: http://www.lamsade.dauphine.fr/) in France [39]. Afterwards, new versions of this method were evolved $[39,40]$. The ELECTRE Iv (electre one vee) added a veto threshold into the method, and the ELECTRE IS (electre one esse) dealt with the imperfect data [40]. The ELECTRE II (electre two) was developed for solving the problems of ranking actions [40, 41]. The ELECTRE III (electre three) was introduced as a more developed one using the pseudocriteria (the thresholds $q_{j}$ and $p_{j}$, the imprecision, and the uncertainty) instead of the true-criteria (the smallest difference in performances makes a strict preference between the comparisons of the alternatives) and the fuzzy binary outranking relations for ranking actions $[40,42,43]$. The ELECTRE IV (electre four) was developed to deal with the problems without working on the relative criteria importance coefficients (unwillingness to present information on the role of the criteria) $[40,41,44]$. The ELECTRE TRI (electre tree), the ELECTRE TRI-B, the ELECTRE TRI-C, the ELECTRE TRI-NC, and the ELECTRE ${ }^{\mathrm{GMS}}$ were the latest ELECTRE methods $[41,44]$. The ELECTRE III $[38,40-45]$ and the ELECTRE IV $[38,40,41,44]$ methods are based on the following principles.

The alternatives or actions or options with only partially known a priori are $A=\left\{a_{1}, a_{2}, \ldots, a_{i}, \ldots, a_{m}\right\}$, where $m$ is potential finite number of alternatives or actions.

The family of defined pseudocriteria is $F=\left\{g_{1}, g_{2}, \ldots\right.$, $\left.g_{j}, \ldots, g_{n}\right\}$ where $n \geq 3$.

The performance of actions or alternatives $a_{i}$ on the pseudocriterion $g_{j}$ is $g_{j}\left(a_{i}\right)$ for all $a_{i} \in A$ and $g_{j} \in F$.

The binary outranking relations are I (indifference: reflexive and symmetric relation), $\mathbf{P}$ (strict preference: nonreflexive and asymmetric relation), $\mathbf{Q}$ (weak preference (hesitation): nonreflexive and asymmetric relation), and $\mathbf{R}$ (incomparability: nonreflexive and symmetric relation). The partial binary outranking relations are shown in Figure 5.

$q_{j}$ is the indifference threshold, $p_{j}$ is the preference threshold, and $v_{j}$ is the veto threshold with respect to the $j$ th criterion $\left(v_{j} \geq p_{j} \geq q_{j}\right.$ : for maximization criteria and for minimization additive inverse).

The researchers and the readers should be aware of the difficulties of choosing the realistic threshold values in the ELECTRE methods [46].

$q_{j}$ is the highest value that beyond this value the difference is clear for the human perception [46].

$p_{j}$ may be selected as at least twice as $q_{j}$ for a case that is the symmetrical about the mean value [46]. 

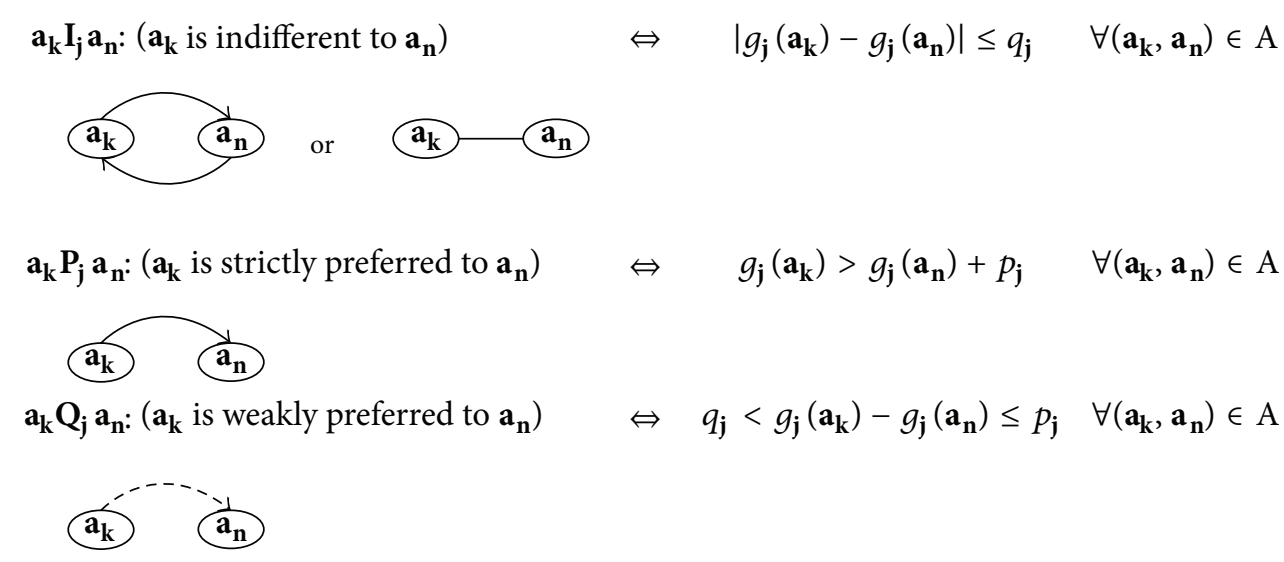

$\mathbf{a}_{\mathbf{k}} \mathbf{R}_{\mathbf{j}} \mathbf{a}_{\mathbf{n}}$ : $\left(\mathbf{a}_{\mathbf{k}}\right.$ is incomparable to $\left.\mathbf{a}_{\mathbf{n}}\right)$

a $a_{n}$

Figure 5

$v_{j}$ may be selected as at least three times as $p_{j}[46]$ :

The voting power of $g_{j}$ is $w_{j}$ and $\sum_{\left\{j \mid g_{j} \in F\right\}} w_{j}=1$.

The group of the strict preference relation, the weak preference relation, and the indifference relation is the partial binary outranking relation: $S_{j}=P_{j} \cup Q_{j} \cup I_{j}\left(>_{j}=Q_{j} \cup P_{j}\right)$.

The comprehensive outranking relation is $S=P \cup Q \cup I$ $(\succ=Q \cup P)$ :

$\mathrm{a}_{\mathrm{k}} \mathrm{Sa} \mathrm{a}_{\mathrm{n}}$ and $\operatorname{not}\left(\mathrm{a}_{\mathbf{n}} \mathrm{Sa}_{\mathrm{k}}\right)$ :

$\left(a_{k}>a_{n}\right) \Longleftrightarrow\left(a_{k}\right.$ is preferred to $\left.a_{n}\right)$

$$
\forall\left(\mathbf{a}_{\mathbf{k}}, \mathbf{a}_{\mathbf{n}}\right) \in A,
$$

$\mathrm{a}_{\mathbf{n}} \mathrm{Sa}_{\mathrm{k}}$ and not $\left(\mathrm{a}_{\mathbf{k}} \mathrm{Sa}_{\mathbf{n}}\right)$ :

$$
\left(a_{n}>a_{k}\right) \Longleftrightarrow\left(a_{n} \text { is preferred to } a_{k}\right)
$$

$$
\forall\left(\mathbf{a}_{\mathbf{k}}, \mathbf{a}_{\mathbf{n}}\right) \in A,
$$

$a_{k} S a_{n}$ and $a_{n} S a_{k}$ :

$\mathbf{a}_{\mathbf{k}} \mathbf{I} \mathbf{a}_{\mathbf{n}} \Longleftrightarrow\left(\mathbf{a}_{\mathbf{k}}\right.$ is indifferent to $\left.\mathbf{a}_{\mathbf{n}}\right)$

$$
\forall\left(\mathbf{a}_{\mathbf{k}}, \mathbf{a}_{\mathbf{n}}\right) \in A,
$$

not $\left(\mathbf{a}_{\mathbf{k}} \mathbf{S} \mathbf{a}_{\mathbf{n}}\right)$ and not $\left(\mathbf{a}_{\mathbf{n}} \mathbf{S} \mathbf{a}_{\mathbf{k}}\right)$ :

$a_{k} \mathbf{R a}_{n} \Longleftrightarrow\left(a_{k}\right.$ is incomparable to $\left.a_{n}\right)$

$$
\forall\left(\mathbf{a}_{\mathbf{k}}, \mathbf{a}_{\mathbf{n}}\right) \in A .
$$

Otherwise $\quad \forall\left(\mathbf{a}_{\mathbf{k}}, \mathbf{a}_{\mathbf{n}}\right) \in \mathrm{A}$

$$
\Leftrightarrow \quad\left|g_{\mathbf{j}}\left(\mathbf{a}_{\mathbf{k}}\right)-g_{\mathbf{j}}\left(\mathbf{a}_{\mathbf{n}}\right)\right| \leq q_{\mathbf{j}} \quad \forall\left(\mathbf{a}_{\mathbf{k}}, \mathbf{a}_{\mathbf{n}}\right) \in \mathrm{A}
$$

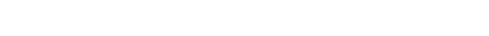

The concordance index (the strength of the positive arguments) of the actions or the alternatives $\left(\mathbf{a}_{\mathbf{k}}, \mathbf{a}_{\mathbf{n}}\right)$ (the values of concordance matrix) is

$$
\begin{aligned}
& c_{j}\left(a_{k}, a_{n}\right) \\
& = \begin{cases}0, & \text { if } g_{j}\left(a_{k}\right) \leq g_{j}\left(a_{n}\right)-p_{j}, \\
0<\frac{p_{j}-\left[g_{j}\left(a_{n}\right)-g_{j}\left(a_{k}\right)\right]}{p_{j}-q_{j}}<1, & \text { if } g_{j}\left(a_{n}\right)-p_{j}<g_{j}\left(a_{k}\right)<g_{j}\left(a_{n}\right)-q_{j}, \\
1, & \text { if } g_{j}\left(a_{k}\right) \geq g_{j}\left(a_{n}\right)-q_{j} .\end{cases}
\end{aligned}
$$

The total or overall or global or comprehensive concordance index is

$$
C\left(a_{k}, a_{n}\right)=\frac{\sum_{j=1}^{n} w_{j} \times c_{j}\left(a_{k}, a_{n}\right)}{\sum_{j=1}^{n} w_{j}},
$$

where $w_{j}$ is the weight of the criterion.

The discordance index (the strength of the opposition) of alternatives $\left(a_{k}, a_{n}\right)$ is

$$
\begin{aligned}
& d_{j}\left(a_{k}, a_{n}\right) \\
& = \begin{cases}0, & \text { if } g_{j}\left(a_{k}\right) \geq g_{j}\left(a_{n}\right)-p_{j}, \\
0< & \frac{p_{j}-\left[g_{j}\left(a_{n}\right)-g_{j}\left(a_{k}\right)\right]}{p_{j}-v_{j}}<1, \\
& \text { if } g_{j}\left(a_{n}\right)-v_{j}<g_{j}\left(a_{k}\right)<g_{j}\left(a_{n}\right)-p_{j}, \\
1, & \text { if } g_{j}\left(a_{k}\right) \leq g_{j}\left(a_{n}\right)-v_{j} .\end{cases}
\end{aligned}
$$


The creditability or the credibility or the credit degree $\sigma_{s}\left(a_{k}, a_{n}\right)$ is

$$
\begin{aligned}
& \bar{F}\left(a_{k}, a_{n}\right)=\left\{j \in F \mid d_{j}\left(a_{k}, a_{n}\right) \geq C\left(a_{k}, a_{n}\right)\right\}, \\
& \sigma_{s}\left(a_{k}, a_{n}\right) \\
& \quad= \begin{cases}C\left(a_{k}, a_{n}\right), & \text { if } \bar{F}\left(a_{k}, a_{n}\right)=\emptyset, \\
C\left(a_{k}, a_{n}\right) \prod_{j \in \bar{F}} \frac{1-d_{j}\left(a_{k}, a_{n}\right)}{1-C\left(a_{k}, a_{n}\right)}, & \text { if } \bar{F}\left(a_{k}, a_{n}\right) \neq \emptyset .\end{cases}
\end{aligned}
$$

The network relation in the ELECTRE III/IV methods is based on $\sigma_{s}\left(a_{k}, a_{n}\right) \geq \lambda$.

The $\lambda$ is called as the cut level and calculated by the highest credibility index and the discrimination threshold. If $\sigma_{s}\left(a_{k}, a_{n}\right)$ is above the $\lambda$ cut level $(0.50 \leq \lambda \leq 1.00$, often $\lambda=0.67)$ then $a_{k}$ outranks $a_{n}$. The $\lambda$-strength and the $\lambda$ weakness is calculated for the ranking procedure. The ranking is based on the descending distillation (from the best to the worst) and the ascending distillation (from the worst to the best). The qualification is gathered by these calculations. The final ranking can be found by the average of distillation chains [47].

There are four levels of binary outranking relations in the ELECTRE IV method as the quasidominance relation $\left(S_{q}\right)$, the canonical-dominance relation $\left(S_{c}\right)$, the pseudodominance relation $\left(S_{p}\right)$, and the veto-dominance relation $\left(S_{v}\right)$ (in some improved ones the subdominance relation $\left(S_{s}\right)$ is added as the fifth relation) $[48,49]$. The ELECTRE IV is not the form of ELECTRE III with the equal criteria weights. The algorithm of the ELECTRE IV method is as follows $[49,50]$ :

$m_{p}\left(a_{k}, a_{n}\right)$ : the number of criteria for which $a_{k}$ is strictly preferred to $a_{n}$;

$m_{q}\left(a_{k}, a_{n}\right)$ : the number of criteria for which $a_{k}$ is weakly preferred to $a_{n}$;

$m_{i}\left(a_{k}, a_{n}\right)$ : the number of criteria for which $a_{k}$ is indifferent to $a_{n}$;

$m_{o}\left(a_{k}, a_{n}\right)=m_{o}\left(a_{n}, a_{k}\right)$ : the number of criteria for which $a_{k}$ has the same evaluation to $a_{n}$.

For any pair of alternatives $\left(a_{k}, a_{n}\right)$,

$$
\begin{aligned}
m= & m_{p}\left(a_{k}, a_{n}\right)+m_{q}\left(a_{k}, a_{n}\right)+m_{i}\left(a_{k}, a_{n}\right)+m_{o}\left(a_{k}, a_{n}\right) \\
& +m_{p}\left(a_{n}, a_{k}\right)+m_{q}\left(a_{n}, a_{k}\right)+m_{i}\left(a_{n}, a_{k}\right),
\end{aligned}
$$

where $m$ is the total number of criteria. Consider

$$
\begin{aligned}
& S_{q}: \text { if } m_{p}\left(a_{n}, a_{k}\right)+m_{q}\left(a_{k}, a_{n}\right)=0 \text { and } m_{i}\left(a_{n}, a_{k}\right) \leq 1+ \\
& m_{i}\left(a_{k}, a_{n}\right)+m_{q}\left(a_{k}, a_{n}\right)+m_{p}\left(a_{k}, a_{n}\right) \text { then } a_{k} S_{q} a_{n} ; \\
& S_{c}: \text { if } m_{p}\left(a_{n}, a_{k}\right)=0 \text { and } m_{q}\left(a_{n}, a_{k}\right) \leq m_{p}\left(a_{k}, a_{n}\right) \text { and } \\
& m_{q}\left(a_{n}, a_{k}\right)+m_{i}\left(a_{n}, a_{k}\right) \leq 1+m_{i}\left(a_{k}, a_{n}\right)+m_{q}\left(a_{k}, a_{n}\right)+ \\
& m_{p}\left(a_{k}, a_{n}\right) \text { then } a_{k} S_{c} a_{n} ; \\
& S_{p}: \text { if } m_{p}\left(a_{n}, a_{k}\right)=0 \text { and } m_{q}\left(a_{n}, a_{k}\right) \leq m_{q}\left(a_{k}, a_{n}\right)+ \\
& m_{p}\left(a_{k}, a_{n}\right) \text { then } a_{k} S_{p} a_{n} ;
\end{aligned}
$$

$S_{v}:$ if $m_{p}\left(a_{n}, a_{k}\right)=0$ and $a_{k} S_{p} a_{n}$ or $m_{q}\left(a_{n}, a_{k}\right)=1$ and no $a_{n} P V_{j} a_{k} \forall j$ and $m_{p}\left(a_{k}, a_{n}\right) \geq(m / 2)$ in which $a_{n} P V_{j} a_{k}:\left(g_{j}\left(a_{n}\right)<g_{j}\left(a_{k}\right)+v_{j}\left(g_{j}\left(a_{k}\right)\right)\right.$ then $a_{k} S_{v} a_{n}$.

The creditability or the credibility or the credit degree $\sigma_{s}\left(a_{k}, a_{n}\right)$ is

$$
\sigma_{s}\left(a_{k}, a_{n}\right)= \begin{cases}1, & \text { if } a_{k} S_{q} a_{n}, \\ 0.8, & \text { if } a_{k} S_{c} a_{n}, \\ 0.6, & \text { if } a_{k} S_{p} a_{n} \\ 0.35, & \text { if } a_{k} S_{v} a_{n}, \\ 0, & \text { if no relation amongs } S_{q}, S_{c}, S_{p}, S_{v} .\end{cases}
$$

There are several objective weight assessment methods such as the extreme weight approach, the random weight approach, and the entropy methods [51]. One of the most appropriate applicable methods is presented as the entropy methods amongst the objective weight assessment methods [51]. There are some criticisms about the entropy methods' closeness to the true weight vector according to the multiplicative error and the additive error when the decision makers' decisions are based on the exponential scale [52]. Despite these criticisms, Shannon's Entropy [53] (Shannon Information by Claude Elwood Shannon so called "the father of information theory") (1916-2001) as below amongst several developed entropy methods such as De Luca and Termini, Szmidt and Kacprzyk [54] was used for the criterion weight assessments in this experimental research study. Shannon's Entropy method was specifically preferred to be used, adopted, and investigated in the current experimental research study to understand the nature and performance of this objective weight assessment method for solving the defined problem in this experimental research study and to observe and predict its adoptability and its usage possibility in the future more sophisticated models (on the research, development, and deployment edge: the computer based intelligent decision making system and the autonomous decision making systems) for the real world cases. The method is shortly as follows [54-57].

The initialized decision matrix is $X=\left(x_{i j}\right)_{n \times m}$, where $i$ is for the criteria $(1 \leq i \leq n)$ and $j$ is for the alternative $(1 \leq j \leq$ $m)$.

The normalized matrix is $R=\left(r_{i j}\right)_{n \times m}$.

The elements of the normalized matrix $r_{i j}$ take the values between 0 and 1 where

$$
r_{i j}=\frac{x_{i j}-\min _{i}\left\{x_{i j}\right\}}{\max _{i}\left\{x_{i j}\right\}-\min _{i}\left\{x_{i j}\right\}}
$$

(for the criterion which is a kind of maximization),

$$
r_{i j}=\frac{\max _{i}\left\{x_{i j}\right\}-x_{i j}}{\max _{i}\left\{x_{i j}\right\}-\min _{i}\left\{x_{i j}\right\}}
$$

(for the criterion which is a kind of minimization). 
The entropy is $e_{i}$ (note in general $H, H(p(x)$, or $H(A))$ ) of the $i$ th criterion as

$$
e_{i}=-k \sum_{j=1}^{m} f_{i j} \ln \left(f_{i j}\right)
$$

where $f_{i j}=\frac{r_{i j}}{\sum_{j=1}^{m} r_{i j}}, \quad k=\frac{1}{\ln (m)}$

when $f_{i j}=0 \Longrightarrow f_{i j} \ln \left(f_{i j}\right)=0$,

the weight of entropy of $i$ th criterion as $w_{i}=\frac{1-e_{i}}{n-\sum_{i=1}^{n} e_{i}}$,

where $0 \leq w_{i} \leq 1, \quad \sum_{i=1}^{n} w_{i}=1$

The subjective criteria weighting by Saaty's AHP (Analytic Hierarchy Process by Thomas L. Saaty) (1926-alive by November 2014) that was based on the pairwise comparisons of the criteria, the geometric mean approximation, and the normalization [58-60] was also used for the criterion weight assessments in this experimental research study. Saaty's AHP method (as for the subjective weight assessment method) was especially chosen to be employed and applied in this experimental research study, because of its capability of taking the experts' thoughts in a free and scientific way according to the experts' experiences and preferences.

Despite the ELECTRE methods have the main recommendation of being applied up to thirteen criteria, it is believed that the current experimental research case study (seventeen criteria) can also be handled with ease by the ELECTRE methods.

The ELECTRE III (for ranking decision), the ELECTRE IV (for ranking decision), Shannon's Entropy (for voting power decision), and Saaty's AHP subjective criteria weighting (for voting power decision) methods were applied and tested in the experimental research case study as presented in the next section.

\section{The Experimental Research Model, Case, Results, and Discussion}

The ELECTRE methods are very effective for solving the problems with large number of actions or alternatives [38-46]. However, only five candidate private SHPP investments in the predevelopment investment stages were investigated during this experimental research case study. The data and information of these candidate PSHPPIs were collected and evaluated according to ten subjective and seven objective criteria. The experimental research model was built and performed by both Microsoft Excel (http://www.microsoft.com) and Apache OpenOffice Calc software (http://www.openoffice.org/). The model files of the experimental research case study in $*$.xls and $*$.ods formats were also available for the readers (correspond and contact to the author and also see the electronic supplementary material). Moreover, it should be mentioned that the electrical installed capacity $P$ (in Watts: W) (see and read [61]) of a SHPP was calculated by the following formula:

$$
P=\eta_{\mathrm{tr}} \times \eta_{g} \times \eta_{t} \times \rho_{w} \times g \times Q \times H,
$$

where $\eta_{\mathrm{tr}}$ is efficiency of transformer, $\eta_{g}$ is efficiency of generator, $\eta_{t}$ is efficiency of turbine, $\rho_{w}$ is density of water $\left(\mathrm{kg} / \mathrm{m}^{3}\right), g$ is gravity $\left(\mathrm{m} / \mathrm{s}^{2}\right), Q$ is design/project discharge $\left(\mathrm{m}^{3} / \mathrm{s}\right)$, and $H$ is net head $(\mathrm{m})$ (J: Joule, kg: kilogram, $\mathrm{m}$ : meter, $\mathrm{N}$ : Newton, s: second, W: Watt) $(\mathrm{W}=\mathrm{J} / \mathrm{s}=\mathrm{N} * \mathrm{~m} / \mathrm{s}=$ $\mathrm{kg} * \mathrm{~m}^{2} / \mathrm{s}^{3}$ ) (for extraction of this formula/equation see and read $[18,62,63])$.

The criteria in the current experimental research study were selected as given in Table 4 based on the state of mind in the positive thinking (please look for the state of mind and the positive thinking terms see and read [64-68]).

The major concentration, interest, effort, and working hours (spent hours) in this experimental research study was not mainly spent on finding, defining, identifying, describing, and selecting the PSHPPIs' selection factors or criteria; instead the main focus and the core research interest of the current experimental research study were applying and testing the mentioned and noticed methods, observing and deeply understanding their ability, capability, and usability, and analyzing their performance on reflecting the decision makers preferences and opinions on the selection of the PSHPPIs' problem area, learning their difficulties for the future real world applications (very large number of criteria sets and actions sets) and solving this experimental case problem. Henceforth, the criteria or factors on this experimental research model were found, gathered, and selected from the previous research studies of the author (please correspond to and contact to the author from the presented e-mail address to get more information about those previous research studies (published/under review/under revisions review/yet unpublished stages) on those subjects). The objective criteria (Cr: criterion) in this experimental research study were such as the catchment area (Cr01), which was taken into account in the current experimental model, because it was one of the important elements that could be affected by the climatic conditions and at the same time influenced the project runoff and the flow rate; the project runoff $(\mathrm{CrO2})$ that was considered in the current experimental model, because it showed the water flown over the earth's surface, generated mainly by the rainfall and the snow, and affected the flow rate; the net head ( $\mathrm{Cr} 03$ ) that was examined in the current experimental model, because it was one of the items that defined the types of the electromechanical equipment and their operation conditions, and at the same time it was a direct variable of the installed capacity and the electricity generation by the PSHPPs; the flow rate (Cr04), which was studied in the current experimental model, because it presented the amount of water that could be run through the water turbines at the defined specific duration, and at the same time it was a direct variable of the installed capacity and the electricity generation by the PSHPPs; the firm energy (Cr05) and the secondary energy (Cr06) that were taken into account in the current experimental model, because they determined directly the gross income or the earnings (so that the net income) of the 
TABLE 4: The criteria description.

\begin{tabular}{|c|c|c|c|c|c|c|}
\hline & $\mathrm{Cr}^{*}$ & Criterion & $\mathrm{SOM}^{* *}$ & $\mathrm{MM}^{+}$ & $S^{\#}$ & Description \\
\hline \multirow{7}{*}{$\begin{array}{l}\text { Objective } \\
\text { criteria }\end{array}$} & Cr01 & $\begin{array}{l}\text { Catchment area } \\
\qquad\left(\mathrm{km}^{2}\right)\end{array}$ & nc & ma & $\mathrm{n}$ & $\begin{array}{l}\text { The approximate numerical value was taken from } \\
\text { information form (General Directorate of State Hydraulic } \\
\text { Works: http://www.dsi.gov.tr) of the SHPP (for the term [16]). }\end{array}$ \\
\hline & Cr02 & $\begin{array}{l}\text { Project runoff } \\
\quad\left(\mathrm{hm}^{3}\right)\end{array}$ & nc & ma & $\mathrm{n}$ & $\begin{array}{l}\text { The approximate numerical value was taken from } \\
\text { information form (for this term [17]). }\end{array}$ \\
\hline & Cr03 & Net head (m) & nc & ma & $\mathrm{n}$ & $\begin{array}{l}\text { The approximate numerical value was taken from } \\
\text { information form (for this term [16]). }\end{array}$ \\
\hline & Cr04 & Flow rate $\left(\mathrm{m}^{3} / \mathrm{s}\right)$ & nc & ma & $\mathrm{n}$ & $\begin{array}{l}\text { The approximate numerical value was taken from } \\
\text { information form (for this term visit [16]) }\end{array}$ \\
\hline & Cr05 & $\begin{array}{l}\text { Firm energy } \\
\quad(\mathrm{GWh})\end{array}$ & nc & ma & $\mathrm{n}$ & $\begin{array}{l}\text { Tthe power delivered during a certain period of the day with } \\
\text { at least } 90-95 \% \text { certainty" [18]. The approximate numerical } \\
\text { value was taken from information form. }\end{array}$ \\
\hline & Cr06 & $\begin{array}{c}\text { Secondary } \\
\text { energy (GWh) }\end{array}$ & nc & ma & $\mathrm{n}$ & $\begin{array}{l}\text { The approximate numerical value was taken from } \\
\text { information form. }\end{array}$ \\
\hline & Cr07 & $\begin{array}{l}\text { Investment cost } \\
\text { (million USD) }\end{array}$ & $\mathrm{nc}$ & $\mathrm{mi}$ & $\mathrm{n}$ & $\begin{array}{l}\text { The approximate numerical value was taken from } \\
\text { information form. The total estimated investment cost was in } \\
\text { US Dollars. The exchange rate was taken from the Central } \\
\text { Bank of the Republic of Turkey (http://www.tcmb.gov.tr) on } \\
\text { 8th of September in } 2013 \text {. }\end{array}$ \\
\hline \multirow{10}{*}{$\begin{array}{l}\text { Subjective } \\
\text { criteria }\end{array}$} & Cr08 & River basin & ptd & $\mathrm{ma}$ & ls & $\begin{array}{l}\text { The main river basins of the projects were evaluated by the } \\
\text { EDMs based on their knowledge and experience. }\end{array}$ \\
\hline & Cr09 & $\begin{array}{l}\text { Conveyance } \\
\text { structure }\end{array}$ & ptd & $\mathrm{ma}$ & ls & $\begin{array}{l}\text { The conveyance structures of the SHPP projects were } \\
\text { evaluated according to the knowledge and the experiences of } \\
\text { the EDMs (for this term [19]). }\end{array}$ \\
\hline & Cr10 & $\begin{array}{l}\text { Community } \\
\text { attitude }\end{array}$ & ptd & $\mathrm{ma}$ & ls & $\begin{array}{l}\text { The local community supportive or opposition opinion about } \\
\text { the SHPPs was investigated in this criterion. }\end{array}$ \\
\hline & Crl1 & Transportation & ptd & $\mathrm{ma}$ & ls & $\begin{array}{l}\text { The availability, flexibility, quality, and conditions of all the } \\
\text { transportation modes were evaluated by the EDMs based on } \\
\text { their knowledge and experience. }\end{array}$ \\
\hline & Cr12 & Topography & ptd & $\mathrm{ma}$ & ls & $\begin{array}{l}\text { The surface shapes and features of SHPPs' site were evaluated } \\
\text { by the EDMs. }\end{array}$ \\
\hline & Cr13 & Geology & ptd & $\mathrm{ma}$ & ls & $\begin{array}{l}\text { The geological conditions and properties of SHPPs' site were } \\
\text { evaluated by the EDMs. }\end{array}$ \\
\hline & Cr14 & $\begin{array}{l}\text { Security } \\
\text { conditions }\end{array}$ & ptd & ma & ls & $\begin{array}{l}\text { The public security, the infrastructure security, and other } \\
\text { security groups were evaluated based on the theft, the } \\
\text { burglary, and other security risks and threats (see }[20,21]) \text { by } \\
\text { the EDMs. }\end{array}$ \\
\hline & Cr15 & $\begin{array}{l}\text { Terrorism } \\
\text { conditions }\end{array}$ & ptd & $\mathrm{ma}$ & ls & $\begin{array}{l}\text { The perceived terrorism risks and threats (see }[22,23] \text { ) were } \\
\text { evaluated by the EDMs. }\end{array}$ \\
\hline & Cr16 & Protected areas & ptd & $\mathrm{ma}$ & ls & $\begin{array}{l}\text { The natural parks, the ecological values, and so forth were } \\
\text { evaluated by the EDMs. }\end{array}$ \\
\hline & Cr17 & $\begin{array}{l}\text { Substation } \\
\text { conditions }\end{array}$ & ptd & $\mathrm{ma}$ & ls & $\begin{array}{l}\text { The conditions of the grid connection were evaluated by the } \\
\text { EDMs. }\end{array}$ \\
\hline
\end{tabular}

${ }^{*} \mathrm{Cr}$ : code, ${ }^{* *}$ SOM: state of mind, nc: no condition because of objective criteria, ptd: positive thinking direction, ${ }^{+}$MM: maximization/minimization: ma: maximization, mi: minimization, ${ }^{\#}$ S: scale: $n$ : numerical scale, 1s: 5-point Likert scale: 1 to 5: the worst to the best, and EDM: expert decision maker. See and visit [24] for square kilometer $\left(\mathrm{km}^{2}\right)$, [25] for cubic hectometer $\left(\mathrm{hm}^{3}\right)$, [26] for meter ( $\left.\mathrm{m}\right)$, [27] for cubic metre per second ( $\left.\mathrm{m}^{3} / \mathrm{s}\right)$, [28] for gigawatt hour (GWh), [29] for million, and [30] for USD.

PSHPPs; and finally the investment cost (Cr07), which was evaluated in this experimental model, so that the financial or economic performance of the PSHPPIs would be tried to be estimated by considering both the income (as a whole) and the cost (as a whole) at the same time. All of these criteria were evaluated concurrently in the current experimental model for not missing and omitting any important issues, subjects, topics, and points and at the same time for having the consistent data and information set, so that it aims to be placed in the safe analysis and investigation actions or alternatives space for the electricity generation amount of the PSHPPIs. The subjective criteria in this experimental research study were such as the river basin (Cr08) (for example, MericErgene River Basin, Marmara River Basin, and Susurluk River Basin in Turkey), which was studied in the current experimental model to put the characteristics and the future 
TABLE 5: The PSHPPIs actions in this experimental case study.

\begin{tabular}{|c|c|c|c|c|c|c|c|c|}
\hline Action & $\begin{array}{l}\mathrm{Cr} 01 \\
\left(\mathrm{~km}^{2}\right) \\
\end{array}$ & $\begin{array}{l}\mathrm{Cr} 02 \\
\left(\mathrm{hm}^{3}\right) \\
\end{array}$ & $\begin{array}{l}\mathrm{Cr} 03 \\
(\mathrm{~m})\end{array}$ & $\begin{array}{l}\text { Cr04 } \\
\left(\mathrm{m}^{3} / \mathrm{s}\right)\end{array}$ & $\begin{array}{c}\text { Cr05 } \\
\text { (GWh) } \\
\end{array}$ & $\begin{array}{c}\text { Cr06 } \\
(\mathrm{GWh}) \\
\end{array}$ & $\begin{array}{c}\text { Cr07 } \\
\text { (Million USD) } \\
\end{array}$ & Cr09 \\
\hline $\mathrm{A} 1$ & 79 & 47 & 369 & 3 & 26 & 15 & 11,5 & $\begin{array}{c}\text { Channel closed } \\
\text { rectangular } 3.900 \mathrm{~m}\end{array}$ \\
\hline $\mathrm{A} 2$ & 61 & 48 & 388 & 3 & 6 & 31 & 7,8 & uPVC pipe $3.300 \mathrm{~m}$ \\
\hline A3 & 329 & 131 & 172 & 8 & 16 & 38 & 16,6 & $\begin{array}{c}\text { Channel open } \\
\text { rectangular } 9.600 \mathrm{~m}\end{array}$ \\
\hline A4 & 130 & 133 & 135 & 10 & 14 & 29 & 24,1 & $\begin{array}{c}\text { Tunnel modified } \\
\text { horseshoe } 8.800 \mathrm{~m}\end{array}$ \\
\hline A5 & 553 & 701 & 97 & 19,5 & 29 & 23 & 27,9 & $\begin{array}{c}\text { Tunnel circular } \\
5.900 \mathrm{~m}\end{array}$ \\
\hline
\end{tabular}

See and read [24] for square kilometer $\left(\mathrm{km}^{2}\right)$, [25] for cubic hectometer $\left(\mathrm{hm}^{3}\right)$, [26] for meter (m), [27] for cubic metre per second $\left(\mathrm{m}^{3} / \mathrm{s}\right)$, [28] for gigawatt hour (GWh), [29] for million, and [30] for USD; see, read, and watch [31] and see and read [32] for some issues about the conveyance structures.

conditions and predictions of the river basins into this model; the conveyance structure (Cr09) (for example, a long tunnel, a short tunnel, an open channel, and several tunnels) that was preferred to be evaluated to try to foresee the difficulties and the obstacles mainly during the construction period and the operation period; the community attitude (Cr10), which was considered in the current experimental model for predicting the supporting activities, the oppositions, the blockages, and the protests against the PSHPPI; the transportation (Cr11) that was evaluated in this experimental model for the difficulties before the construction period, during the construction period and during the operational period; the topography (Cr12), which was put into the current experimental model for the difficulties and the easiness of the activities for the construction and the investigations and the engineering studies before the construction period, during the construction and operational periods; the geology (Cr13), which was taken into account in the current experimental model, because the activities and all of the design and construction works were related with this factor; the security conditions (Cr14) that was considered in this experimental model for predicting the difficulties such as the security risks and threats for the private life, the public life, and the infrastructure before the construction period and during the construction and operational periods; the terrorism conditions ( $\mathrm{Cr} 15)$ that were taken into account because of the same reasons with the security conditions, but with a devastating effect such as the civil disorder, the political, the nonpolitical, the ideological, and the official or state terrorisms; the protected areas (Cr16) (for example, the cultural values, the natural parks, the important bird areas, and the rainforests) that was evaluated for predicting the permission works and also the community attitude and at the same time for having environmentally friendly, compatible, and responsible PSHPPs; and finally the substation conditions (Cr17), which was studied for analyzing the connection to the grid possibilities and conditions before and during the construction period and the easiness and the ability of the operation and the maintenance of the connection lines during the construction period. All of these criteria were thought to be evaluated by the healthy, honest, fair, reliable, straightforward, trustworthy, and pragmatic experts and decision makers (in other words not ill, unhealthy, dishonest, unfair, unreliable, unreasonable, insincere, and untrustworthy) under the normal conditions (for instance, not under any duress, coercion, threat, violence, mobbing, and bullying).

The actions or alternatives or options in the current experimental research study were found and taken from the PSHPPIs portfolio in Turkey (please consider, think, and imagine all of the private power plants in Turkey as a whole private investment portfolio set for the real sectors' foreign or domestic or local private investors; moreover please keep in mind that the private small hydropower plants investment set is a subset of this whole private investment portfolio set), which could be accepted and assumed as free or available or ready to be sold or exchanged some of its shares and stocks in the predevelopment investment stages. The main characteristics of these actions were gathered from the PSHPPIs official records on the open sources as some of them presented in Table 5.

The experimental research model of the current study was founded on the EDM's preferences and evaluations; henceforth the main decision making process was supported by the ELECTRE III (ranking) and Saaty's AHP (voting power) (imagine like the highway); the experimental decision making process had three main sections or parts (imagine like the sideways) as the ELECTRE III (ranking) and Shannon's Entropy (voting power), the ELECTRE III (ranking) and the Equal Weighting (voting power), and the ELECTRE IV. In addition to these main sections (methods and approaches), three $\lambda$ cut levels were used for the investigation and the analysis of the discrimination and the distinction of the actions or the alternatives in this experimental research study. The experimental research model was tried to be presented by the help of Figure 6.

In the current experimental case study, there were two experts, who were also the decision makers (a group decision making case). This condition made the use of the expert decision maker (EDM) term possible. The expert decision makers $\left(\mathrm{EDM}_{1}\right.$ and $\mathrm{EDM}_{2}$ : multidisciplinary experts) were capable of evaluating all of these criteria in a sufficient manner. The EDMs took their weighting power (weight of the 


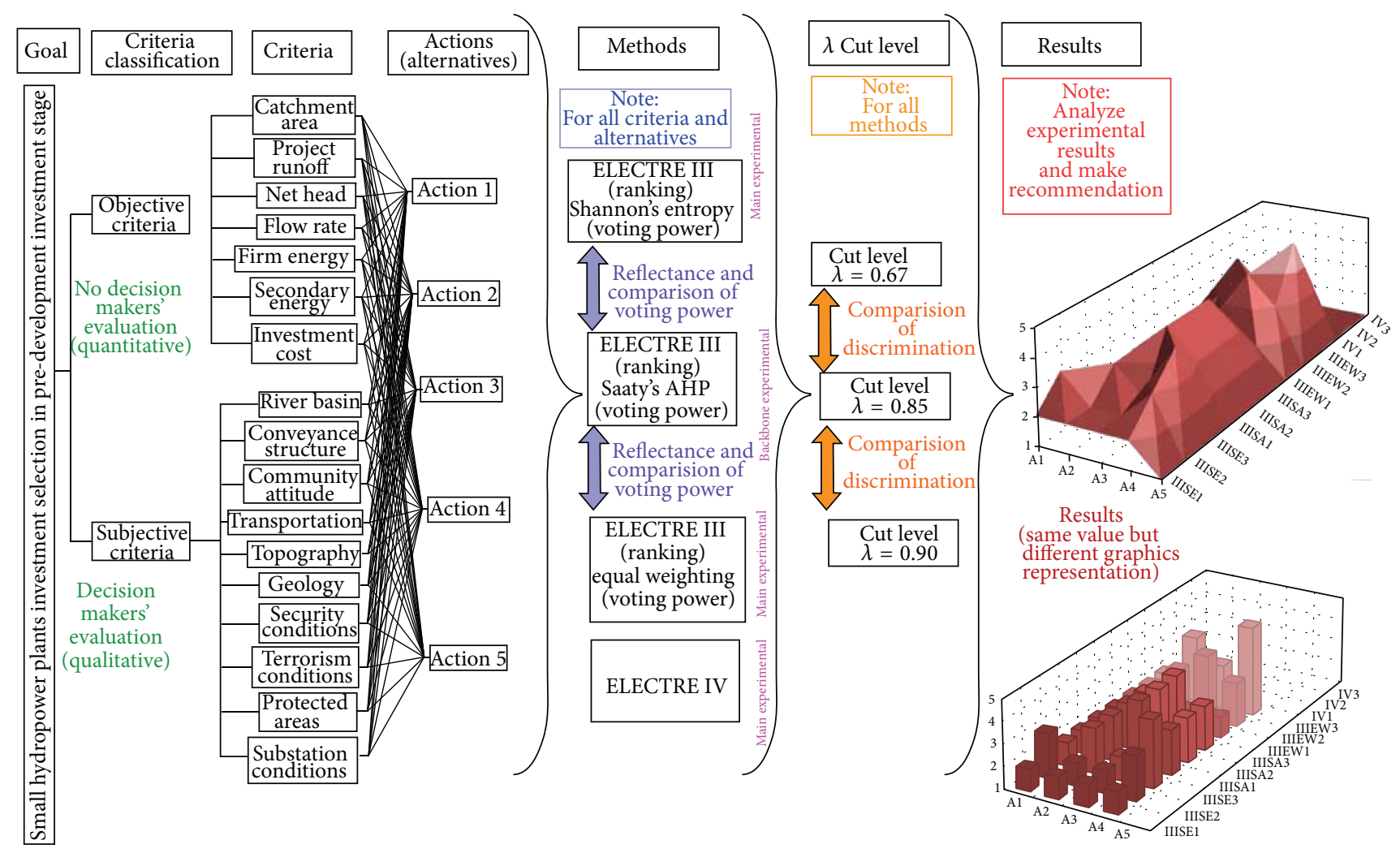

FIGURE 6: The experimental research model (generated by the Apache OpenOffice 4.1.0 Draw).

EDM) on the decision process by their practical experience in the industry and the educational background (bachelor, master, and doctoral degrees in the engineering fields).

The subjective criteria were evaluated by the Likert 5 type scale (by Likert: 1903-1981) [69] and the linguistic or verbal statements considering the basic principles of the human mind cognitive capacity such as the magical number 7, $7 \pm 2$ rule (by Miller (1920-2012), Shiffrin (1968-alive by November 2014) and Nosofsky (alive by November 2014)) $[70,71]$ and the verbal qualifiers (by Rohrmann (alive by November 2014)) [72] as presented in Table 6.

The criteria weights were found by Shannon's Entropy method (objective weighting) and by Saaty's AHP method (subjective weighting) as shown in Figure 7. The consistency ratios of the EDMs' evaluations were found as $9.9 \%$ and 9.7\%, respectively, in Saaty's AHP method for the criteria weighting, which were less than $10 \%$ and in the acceptable levels. Shannon's Entropy method calculated the highest priority for the project runoff, the catchment area, the flow rate, and the community attitude criteria, respectively. The EDMs gave the highest priority to the terrorism, the substation, and the security, respectively, as calculated by Saaty's AHP method for the criteria. The difference of the values between Shannon's Entropy and Saaty's AHP method for the project runoff, the catchment area, the flow rate, the community attitude, the terrorism, the substation, and the security criteria were $0.1193\left(\mathrm{EDM}_{1}\right)$ and $0.1155\left(\mathrm{EDM}_{2}\right)$; $0.0780\left(\mathrm{EDM}_{1}\right)$ and $0.0782\left(\mathrm{EDM}_{2}\right) ; 0.0509\left(\mathrm{EDM}_{1}\right)$ and
$0.0498\left(\mathrm{EDM}_{2}\right) ; 0.0639\left(\mathrm{EDM}_{1}\right)$ and $0.0658\left(\mathrm{EDM}_{2}\right) ;-0.1419$ $\left(\mathrm{EDM}_{1}\right)$ and $-0.1418\left(\mathrm{EDM}_{2}\right) ;-0.1111\left(\mathrm{EDM}_{1}\right)$ and -0.1235 $\left(\mathrm{EDM}_{2}\right) ;-0.1038\left(\mathrm{EDM}_{1}\right),-0.0864\left(\mathrm{EDM}_{2}\right)$, respectively. These experimental results showed that Shannon's Entropy method was not able to reflect exactly the EDMs' perception on the criteria calculated by Saaty's AHP method in this particular experimental case (Figure 7) (note: important finding for this experimental research model, and this experimental research case).

The $\mathrm{EDM}_{1}$ took the weight of 0.4 and the $\mathrm{EDM}_{2}$ took the weight of 0.6 by the agreed upon point of view and the consensus of the EDMs, because of being not only based on their experience and knowledge on the PSHPPIs, but also according to their specific and particular interest, attention, consideration, focus, and examination on the current experimental research case. The evaluations for all criteria of the EDMs were compared and checked with each other as presented in Figure 8.

The performance of the alternatives, the indifference thresholds, the preference thresholds, the veto thresholds and the criterion weights of criteria for the EDMs, and the percentage of the differences of these performances, thresholds, weights, and the characteristics of the EDMs made the aggregation process sufficiently acceptable and possible by (12) and (13) as the IDAMS (Internationally Developed Data Analysis and Management Software) of the UNESCO (United Nations Educational, Scientific and Cultural Organization) (see some issues for the principle approaches [73-82]). 

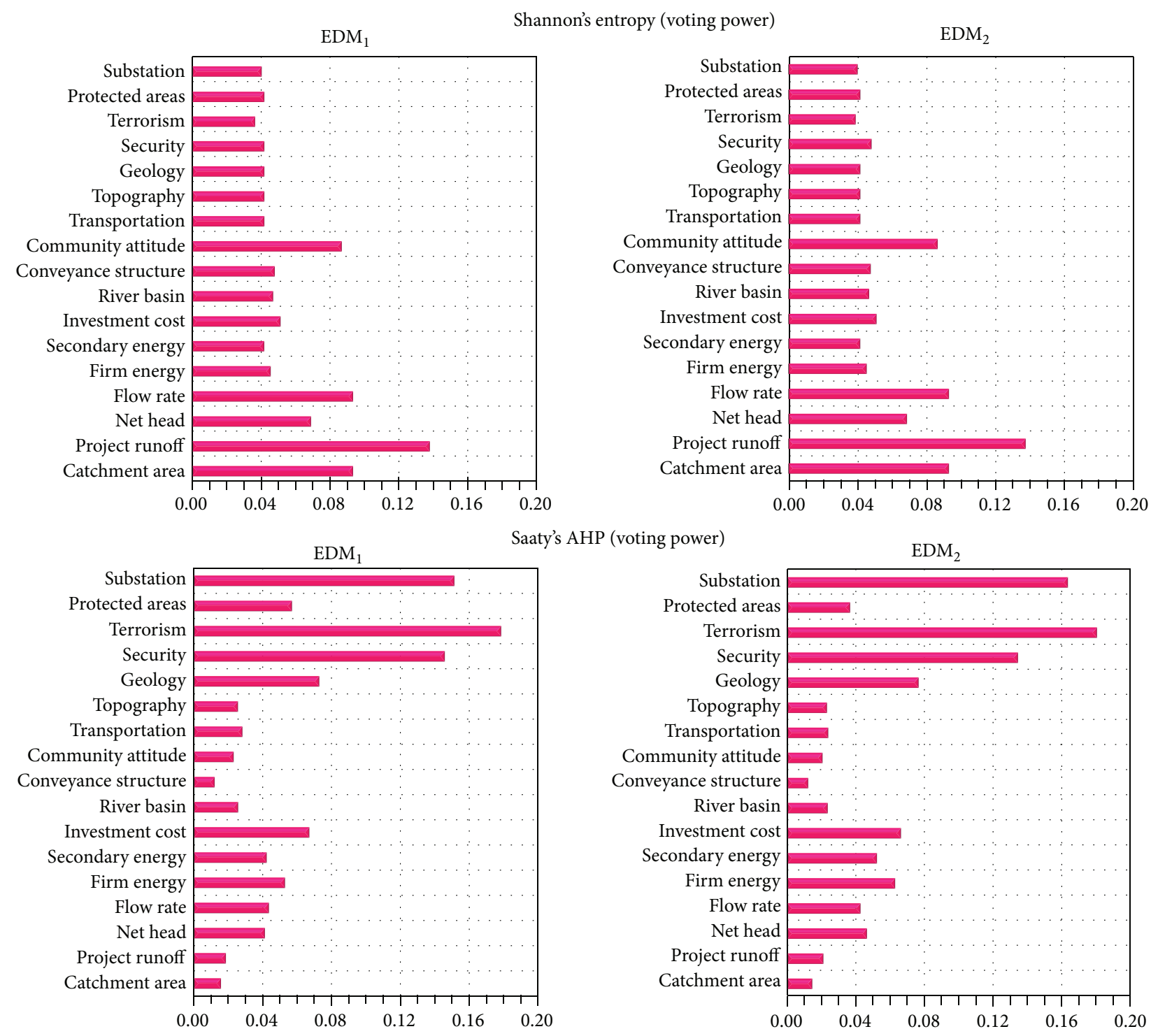

Reflectance of Shannon's entropy for Saaty's AHP (comparison of voting power)
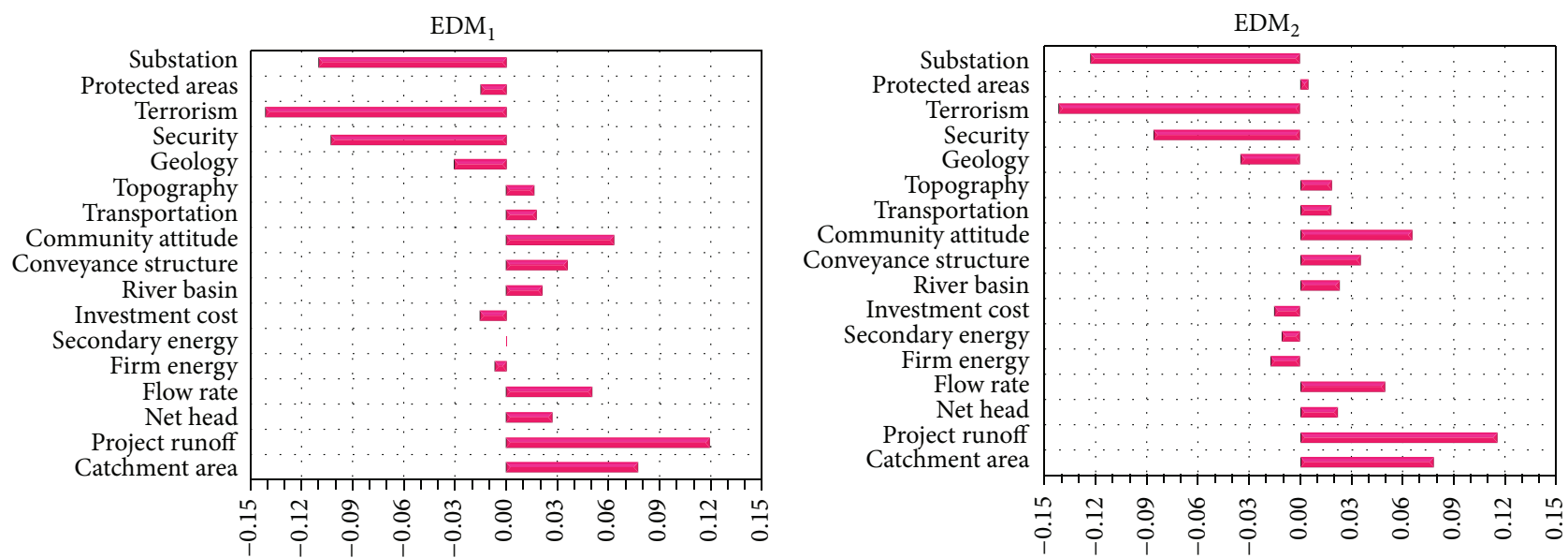

FIgURE 7: The objective and the subjective criteria evaluations by the EDMs (generated by the Microsoft Office Excel 2007). 
TABLE 6: The subjective criteria evaluation by the EDMs.

\begin{tabular}{|c|c|c|c|c|c|c|c|}
\hline \multicolumn{2}{|c|}{ Subjective criteria } & \multicolumn{6}{|c|}{ Actions (alternatives) } \\
\hline Code & Name & Direction of preference & $\mathrm{A} 1$ & $\mathrm{~A} 2$ & A3 & A4 & A5 \\
\hline \multicolumn{8}{|c|}{ Expert decision maker $1\left(\mathrm{EDM}_{1}\right)$} \\
\hline Cr08 & River basin & $\operatorname{Max}$ & VB & G & $\mathrm{B}$ & VG & VG \\
\hline Cr09 & Conveyance structure & Max & G & VG & A & $\mathrm{VB}$ & $\mathrm{B}$ \\
\hline Cr10 & Community attitude & Max & A & $\mathrm{B}$ & G & $\mathrm{VB}$ & VB \\
\hline Cr11 & Transportation & Max & VG & B & A & G & G \\
\hline Cr12 & Topography & Max & VG & B & A & G & G \\
\hline Cr13 & Geology & Max & G & B & $\mathrm{VB}$ & A & A \\
\hline Cr14 & Security conditions & Max & VG & G & $\mathrm{B}$ & G & A \\
\hline Cr15 & Terrorism conditions & Max & VG & $\mathrm{A}$ & $\mathrm{VB}$ & G & G \\
\hline Cr16 & Protected areas & Max & $\mathrm{B}$ & A & VG & G & G \\
\hline Cr17 & Substation conditions & Max & $\mathrm{B}$ & G & $\mathrm{A}$ & $\mathrm{A}$ & $\mathrm{A}$ \\
\hline \multicolumn{8}{|c|}{ Expert decision maker $2\left(\mathrm{EDM}_{2}\right)$} \\
\hline Cr08 & River basin & $\operatorname{Max}$ & VB & G & $\mathrm{B}$ & VG & VG \\
\hline Cr09 & Conveyance structure & Max & G & VG & A & VB & $\mathrm{B}$ \\
\hline Cr10 & Community attitude & Max & A & B & G & $\mathrm{VB}$ & VB \\
\hline Cr11 & Transportation & Max & VG & B & A & G & G \\
\hline Cr12 & Topography & Max & VG & B & A & G & G \\
\hline Cr13 & Geology & Max & $\mathrm{G}$ & B & VB & A & A \\
\hline Cr14 & Security conditions & Max & VG & G & B & $\mathrm{A}$ & A \\
\hline Cr15 & Terrorism conditions & Max & VG & A & VB & A & G \\
\hline Cr16 & Protected areas & Max & B & $\mathrm{A}$ & VG & G & G \\
\hline Cr17 & Substation conditions & Max & $\mathrm{B}$ & G & $\mathrm{A}$ & $\mathrm{A}$ & $\mathrm{A}$ \\
\hline
\end{tabular}

Linguistic or verbal statements.

(5) VG: very good; (4) G: good; (3) A: average; (2) B: bad; (1) VB: very bad.

The threshold values were defined based on the principles explained in the previous section as in Table 7 . Consider

The concordance index: $c_{j}\left(a_{k}, a_{n}\right)=\frac{\sum_{z=1}^{y y} w_{z} \times c_{j z}\left(a_{k}, a_{n}\right)}{\sum_{z=1}^{y y} w_{z}}$,

where $z$ indicates the experts as $Z=\left\{z_{1}, z_{2}, \ldots, z_{i}, \ldots, z_{y y}\right\}$. Consider

The weight of the criterion: $w_{j}=\frac{\sum_{z=1}^{y y} w_{z} \times w_{j z}}{\sum_{z=1}^{y y} w_{z}}$,

The discordance index: $d_{j}\left(a_{k}, a_{n}\right)=\frac{\sum_{z=1}^{y y} w_{z} \times d_{j z}\left(a_{k}, a_{n}\right)}{\sum_{z=1}^{y y} w_{z}}$.

In the current experimental case study, the experimental model was built upon the consideration of the main features, the criticisms, the improvements, and the new approaches for the ELECTRE methods (see [44]). The credibility (degree) matrices of the ELECTRE III with the objective weighting (Shannon's Entropy), the ELECTRE III with the subjective weighting (Saaty's AHP), the ELECTRE III with the Equal Weighting, and the ELECTRE IV were calculated and presented as shown in Table 8 .

The $\lambda$ cut level was first selected as $(\lambda=0.67)$, then $(\lambda=$ $0.85)$, and $(\lambda=0.90)$.
The decending distilation process and the ascending distilation process (upward and downward distilation) were calculated from the credibility matrices by the help of the sum of the elements of each row and the sum of the elements of each column. The sum of the elements in each row presented the strength of the criterion and the sum of the elements in each column showed the weakness of the criterion. The calculations were also checked by the help of the relation graphs as shown in Figures 9 and 10 (see the electronic supplementary material in the Supplementary Material available online at http://dx.doi.org/10.1155/2015/548460 for the whole details of the calculations).

The ranks for each method and for each $\lambda$ cut level were gathered to make the final decision and to deeply understand and analyze the nature of the methods and the approaches in the current experimental research study as presented in Table 9.

The ELECTRE III (ranking) with Shannon's Entropy (voting power) in the $0.67 \lambda$ cut level gave the preference of the PSHPPIs (the rankings of the actions or the alternatives) as Action or Alternative 5 in the first rank, Action 1, Action 2, Action 3, and Action 4 in the second rank. The discrimination or separation or partition in this experimental case was not definite or distinct as only two preference or selection or rank sets ( 1 and 2 ) could be found in the results and findings. The rankings of the PSHPPIs in the $0.85 \lambda$ cut level were Action or Alternative 5 in the first rank, Action 2 and Action 3 in 

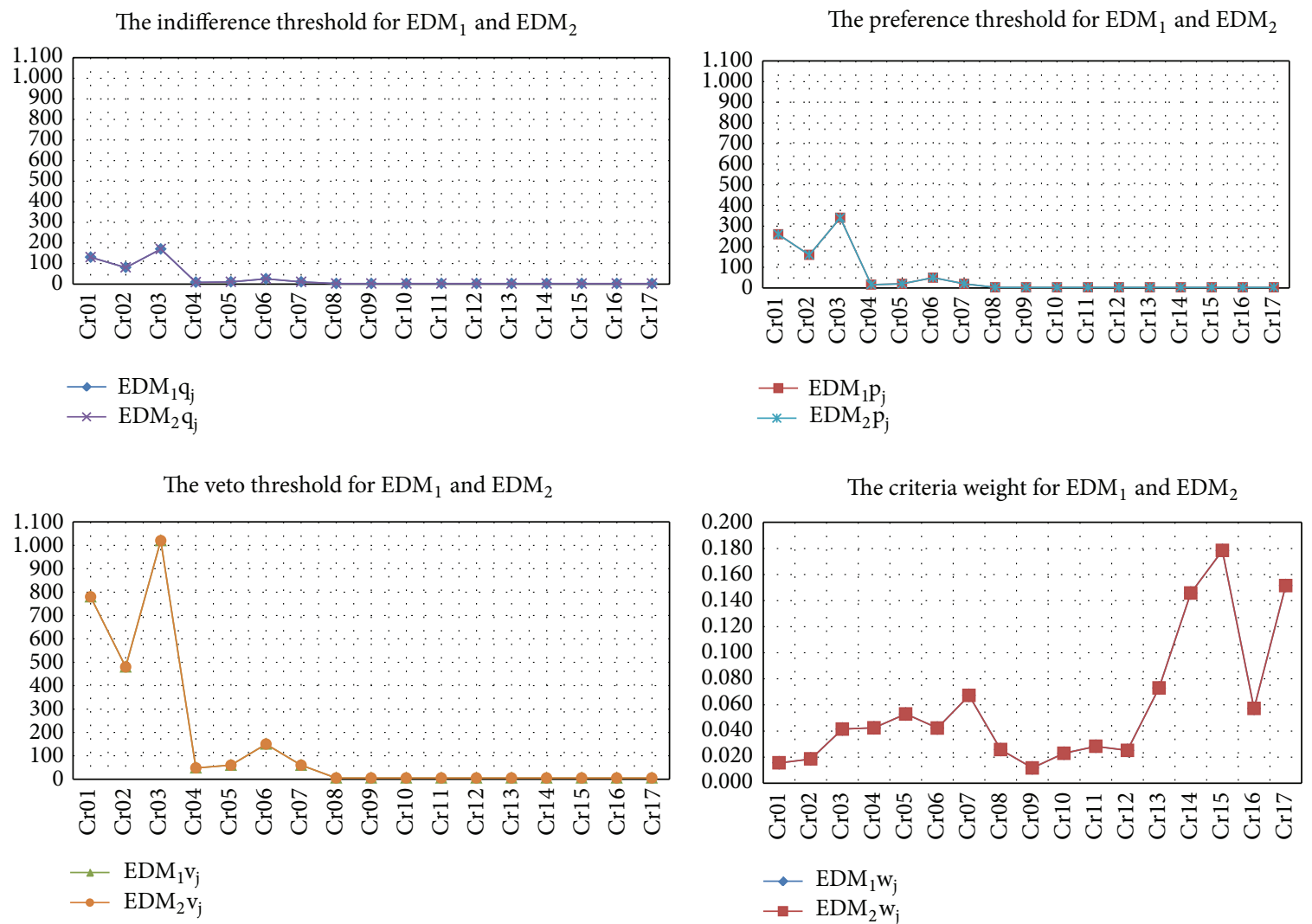

FIGURE 8: The indifference threshold, the preference threshold, the veto threshold, and the criteria weight of the EDMs (generated by the Microsoft Office Excel 2007).
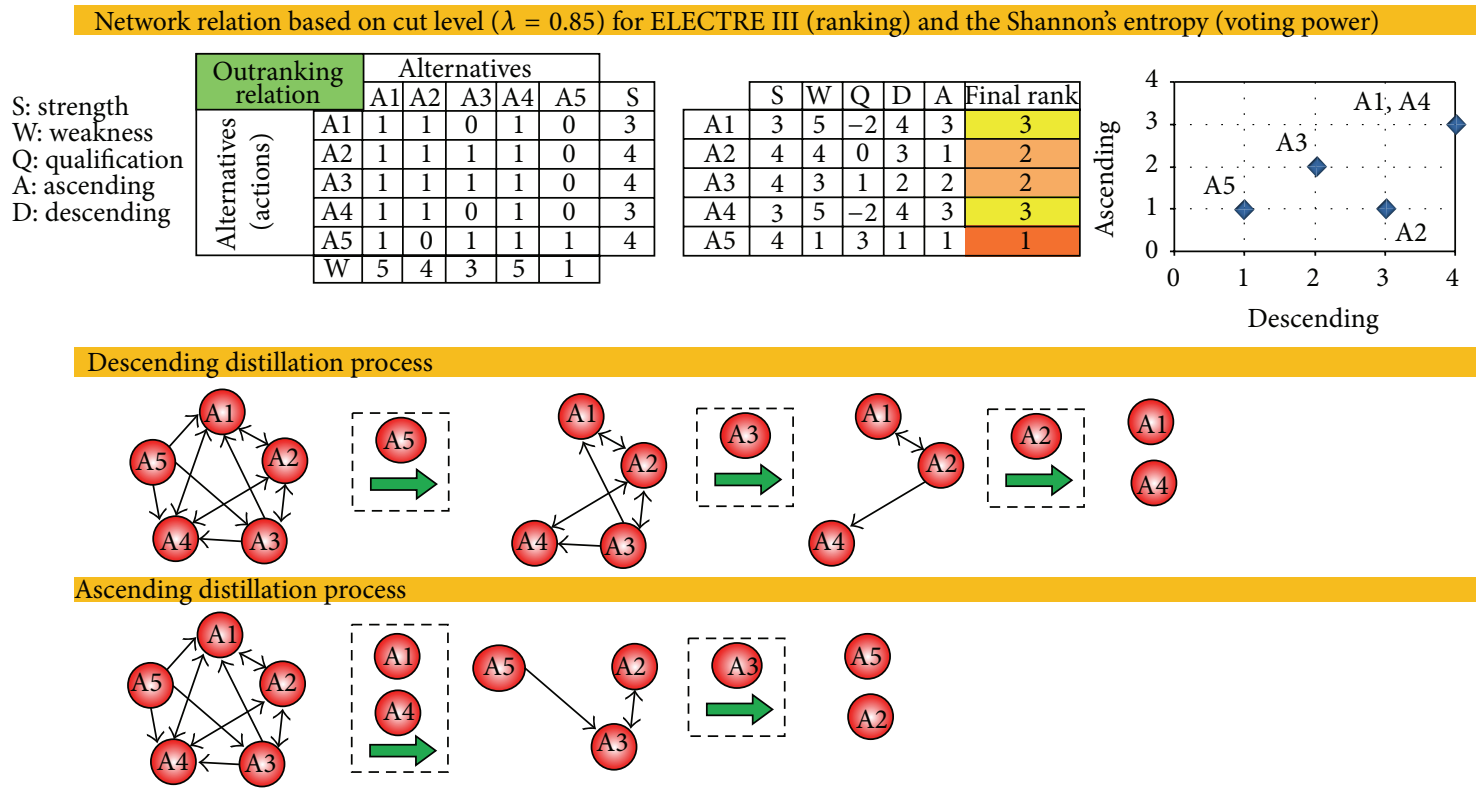

FIGURE 9: The descending distillation process and the ascending distillation process I (see the electronic supplementary material for the whole details of the calculations). 
TABLE 7: The threshold values.

\begin{tabular}{|c|c|c|c|c|c|c|}
\hline \multirow{2}{*}{ Criterion } & \multicolumn{3}{|c|}{$\mathrm{EDM}_{1}$} & \multicolumn{3}{|c|}{$\mathrm{EDM}_{2}$} \\
\hline & Indifference $q_{j}$ & Preference $p_{j}$ & Veto $v_{j}$ & Indifference $q_{j}$ & Preference $p_{j}$ & Veto $v_{j}$ \\
\hline $\mathrm{Cr} 01$ & 130 & 260 & 780 & 100 & 200 & 600 \\
\hline $\mathrm{Cr} 02$ & 80 & 160 & 480 & 60 & 120 & 360 \\
\hline Cr03 & 170 & 340 & 1.020 & 160 & 320 & 960 \\
\hline Cr04 & 8 & 16 & 48 & 6 & 12 & 36 \\
\hline Cr05 & 10 & 20 & 60 & 9 & 18 & 54 \\
\hline Cr06 & 25 & 50 & 150 & 20 & 40 & 120 \\
\hline $\mathrm{Cr} 07$ & 10 & 20 & 60 & 9 & 18 & 54 \\
\hline Cr08-Cr17* & 2 & 3 & 5 & 2 & 3 & 5 \\
\hline
\end{tabular}

${ }^{*}$ Same value from Cr08 to Cr17.

TABLE 8: The creditability or the credibility degrees and matrix for all methods.

\begin{tabular}{|c|c|c|c|c|c|c|}
\hline \multirow[t]{2}{*}{ Methods } & \multicolumn{6}{|c|}{ Credibility matrices } \\
\hline & & $\mathrm{A} 1$ & A2 & $\mathrm{A} 3$ & A4 & A5 \\
\hline \multirow{5}{*}{$\begin{array}{l}\text { ELECTRE III } \\
\text { (ranking) } \\
\text { Shannon's Entropy } \\
\text { (voting power) }\end{array}$} & $\mathrm{A} 1$ & 1.000 & 0.953 & 0.829 & 0.904 & 0.000 \\
\hline & $\mathrm{A} 2$ & 0.871 & 1.000 & 0.870 & 0.953 & 0.000 \\
\hline & A3 & 0.858 & 0.978 & 1.000 & 0.938 & 0.000 \\
\hline & $\mathrm{A} 4$ & 0.893 & 0.878 & 0.839 & 1.000 & 0.000 \\
\hline & A5 & 0.916 & 0.848 & 0.903 & 1.000 & 1.000 \\
\hline \multirow{6}{*}{$\begin{array}{l}\text { ELECTRE III } \\
\text { (ranking) } \\
\text { Saaty's AHP } \\
\text { (voting power) }\end{array}$} & & $\mathrm{A} 1$ & $\mathrm{~A} 2$ & A3 & $\mathrm{A} 4$ & A5 \\
\hline & $\mathrm{A} 1$ & 1.000 & 0.976 & 0.931 & 0.966 & 0.000 \\
\hline & $\mathrm{A} 2$ & 0.892 & 1.000 & 0.976 & 0.990 & 0.000 \\
\hline & A3 & 0.594 & 0.986 & 1.000 & 0.904 & 0.000 \\
\hline & A4 & 0.929 & 0.915 & 0.967 & 1.000 & 0.000 \\
\hline & A5 & 0.920 & 0.887 & 0.965 & 1.000 & 1.000 \\
\hline \multirow{6}{*}{$\begin{array}{l}\text { ELECTRE III } \\
\text { (ranking) } \\
\text { Equal Weighting } \\
\text { (voting power) }\end{array}$} & & $\mathrm{A} 1$ & $\mathrm{~A} 2$ & A3 & $\mathrm{A} 4$ & A5 \\
\hline & $\mathrm{A} 1$ & 1.000 & 0.941 & 0.864 & 0.918 & 0.000 \\
\hline & $\mathrm{A} 2$ & 0.823 & 1.000 & 0.923 & 0.978 & 0.000 \\
\hline & A3 & 0.808 & 0.981 & 1.000 & 0.918 & 0.000 \\
\hline & A4 & 0.879 & 0.866 & 0.894 & 1.000 & 0.000 \\
\hline & A5 & 0.917 & 0.837 & 0.929 & 1.000 & 1.000 \\
\hline \multirow{6}{*}{ ELECTRE IV } & & $\mathrm{A} 1$ & A2 & A3 & $\mathrm{A} 4$ & A5 \\
\hline & $\mathrm{A} 1$ & 1.000 & 0.000 & 0.000 & 0.000 & 0.000 \\
\hline & $\mathrm{A} 2$ & 0.000 & 1.000 & 0.000 & 0.000 & 0.000 \\
\hline & A3 & 0.000 & 0.000 & 1.000 & 0.800 & 0.000 \\
\hline & $\mathrm{A} 4$ & 0.000 & 0.000 & 0.800 & 1.000 & 0.000 \\
\hline & A5 & 0.000 & 0.000 & 0.000 & 0.000 & 1.000 \\
\hline
\end{tabular}

the second rank, and Action 1 and Action 4 in the third rank. The discrimination in this one $(\lambda=0.85)$ was more clear than the previous one $(\lambda=0.67)$ as three selection sets $(1$, 2 , and 3 ) could be found in the results and the findings. The rankings of the PSHPPIs in the $0.90 \lambda$ cut level were Action or Alternative 5 in the first rank, Action 1 and Action 3 in the second rank, Action 2 in the third rank, and Action 4 in the fourth rank. The discrimination in this one $(\lambda=0.90)$ was the most recognizable and definite one $(\lambda=0.85, \lambda=$ $0.67)$ as four selection sets $(1,2,3$, and 4$)$ could be found in the results and the findings. All of the final rankings in the current experimental research study are presented in Figure 11 to give an a whole overview of the methods (for ranking and voting power) and the ranks. Action 5 was positioned in the first rank by all of the methods and $\lambda$ cut levels according to the preferences (the indifference threshold, the preference threshold, the veto threshold, and the criteria weight) of the EDMs in this experimental research case (see Table 9). Action 1 was positioned in the second rank by all of the methods and $\lambda$ cut levels except the ELECTRE III (ranking) with Shannon's Entropy (voting power) at the $\lambda$ cut level of 0.85 and the ELECTRE IV based on the preferences of the EDMs (see 
TABLE 9: The ranks for each method and for each $\lambda$ cut level.

\begin{tabular}{|c|c|c|c|c|c|c|c|}
\hline Methods & $\lambda$ cut level & A1 & A2 & A3 & A4 & A5 & Abbreviation on Figure 11 \\
\hline \multirow{3}{*}{$\begin{array}{l}\text { ELECTRE III } \\
\text { Shannon's Entropy }\end{array}$} & 0.67 & 2 & 2 & 2 & 2 & 1 & IIISE1 \\
\hline & 0.85 & 3 & 2 & 2 & 3 & 1 & IIISE2 \\
\hline & 0.90 & 2 & 3 & 2 & 4 & 1 & IIISE3 \\
\hline \multirow{3}{*}{$\begin{array}{l}\text { ELECTRE III } \\
\text { Saaty's AHP }\end{array}$} & 0.67 & 2 & 3 & 4 & 3 & 1 & IIISA1 \\
\hline & 0.85 & 2 & 3 & 4 & 3 & 1 & IIISA2 \\
\hline & 0.90 & 2 & 3 & 4 & 3 & 1 & IIISA3 \\
\hline \multirow{3}{*}{$\begin{array}{l}\text { ELECTRE III } \\
\text { Equal Weighting }\end{array}$} & 0.67 & 2 & 2 & 2 & 2 & 1 & IIIEW1 \\
\hline & 0.85 & 2 & 3 & 4 & 3 & 1 & IIIEW2 \\
\hline & 0.90 & 2 & 4 & 3 & 5 & 1 & IIIEW3 \\
\hline \multirow{3}{*}{ ELECTRE IV } & 0.67 & 1 & 1 & 1 & 1 & 1 & IV1 \\
\hline & 0.85 & 1 & 1 & 1 & 1 & 1 & IV2 \\
\hline & 0.90 & 1 & 1 & 1 & 1 & 1 & IV3 \\
\hline
\end{tabular}
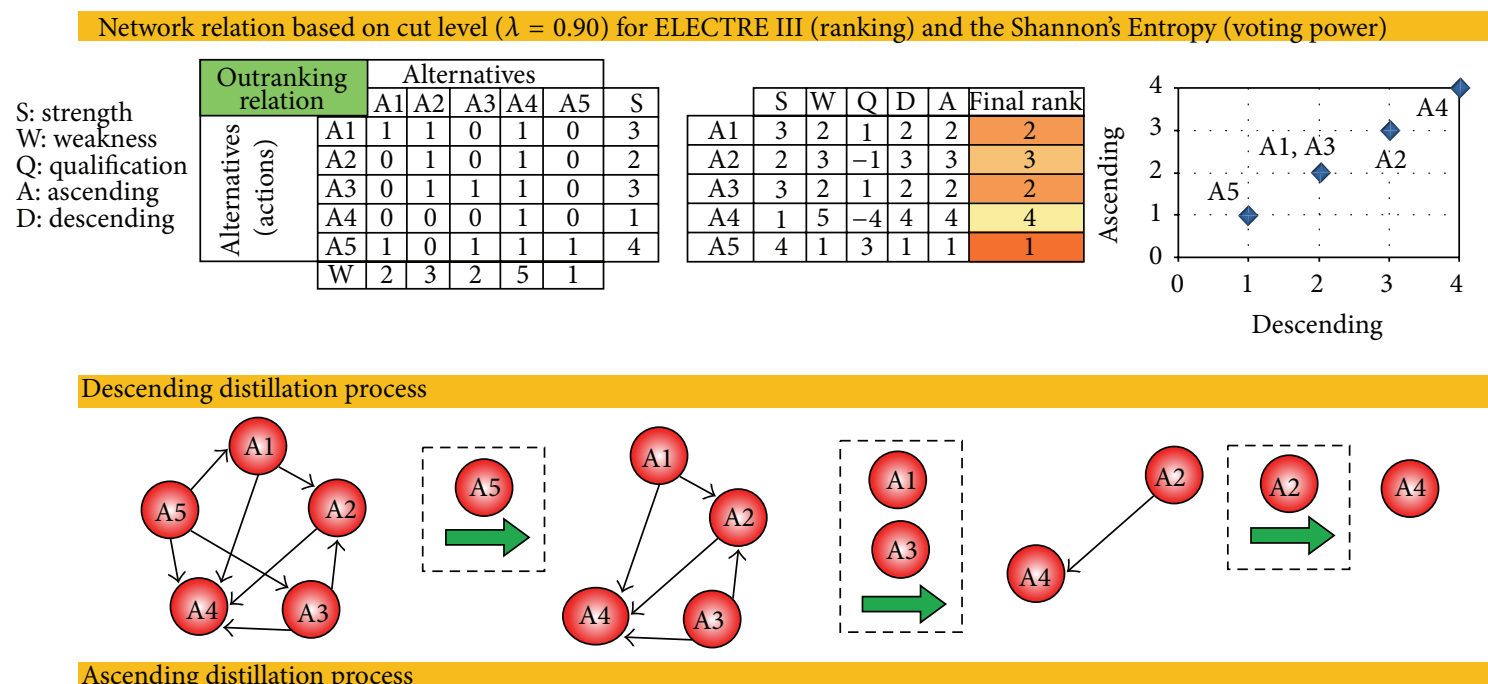

Ascending distillation process
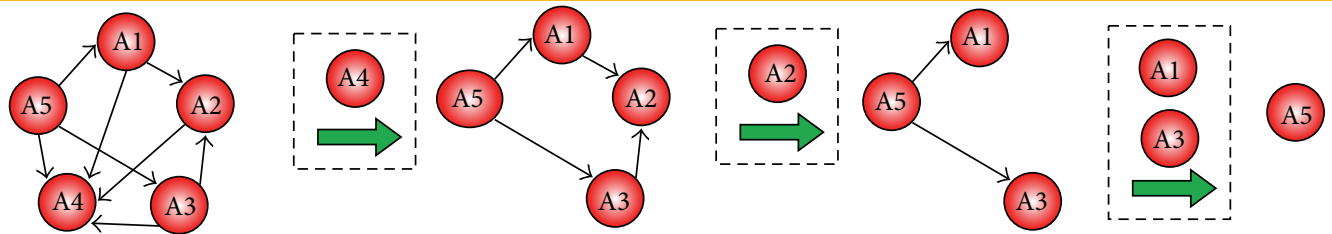

FIgURE 10: The descending distillation process and the ascending distillation process II (see the electronic supplementary material for the whole details of the calculations) (generated by the Microsoft Office Excel 2007).

Table 9). Action 2 was stood in the three highest, two lowest, and seven middle rank selection sets or classes. Action 3 had three highest ranks, three middle ranks, and six lowest ranks. Action 4 was included in three highest, four middle, and five lowest rank selection sets. It was observed in this experimental research study that the ELECTRE IV was not helpful for the discrimination or separation or partition of the current actions or alternatives under these preferences of the EDMs, so that the ELECTRE IV could not be expressed or accepted as a responsive or sensible or sensitive method in the current experimental research case. The ELECTRE III (ranking) with Saaty's AHP (voting power) method gave the same ranks and classification (Action 5: 1st, Action 1: 2nd;
Action 2 and 4: 3rd; Action 3: 4th) in all of the $\lambda$ cut levels $(\lambda=$ $0.67, \lambda=0.85$, and $\lambda=0.90)$. These findings and exploration on the ELECTRE III Saaty's AHP method showed that the $\lambda$ cut levels did not make any difference in the results and the findings of this experimental research case. Moreover, this experimental research study presented that the reflectance of the ELECTRE III and Shannon's Entropy method and the ELECTRE III and the Equal Weighting method on the ELECTRE III and Saaty's AHP method got higher and higher values, while the $\lambda$ cut levels got higher and higher values.

The final rankings and the overall results were also finally discussed by the EDMs in the current experimental research study and it was agreed upon that Action or Alternative 5 then 
Surface view of the final ranks of the ranking methods and the voting power for each $\lambda$ cut level

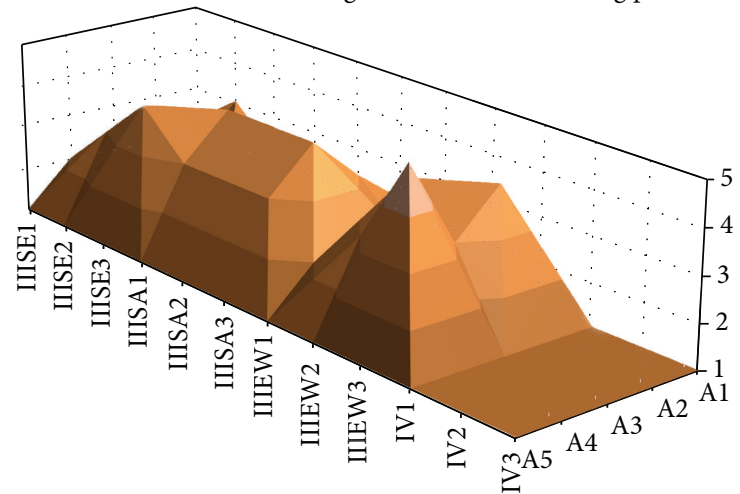

Bar chart view of the final ranks of the ranking methods and the voting power for each $\lambda$ cut level

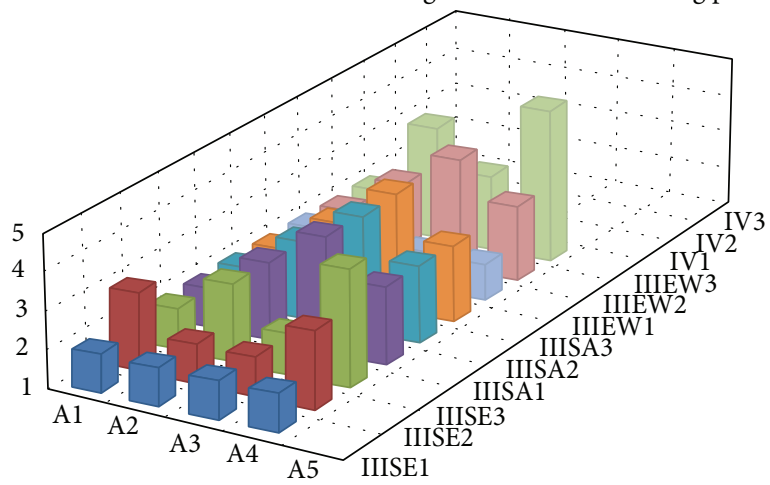

FIGURE 11: The final ranks of the experimental research case study (surface view: generated by the Microsoft Office Excel 2007, bar chart view: generated by the Apache OpenOffice Calc).

Action 1 took the highest ranks, Action 3 took the lowest rank, and Action 2 and Action 4 took the middle ranks. Henceforth, Action or Alternative 5 and the Action 1 had to be moved into the development investment stages of the PSHPPIs. The other alternatives had to be studied after these two PSHPPIs.

\section{Conclusions, Future Applications, and Research}

In this experimental research study, the solution of a private SHPP projects' investment selection problem in Turkey was tried to be solved by the help of mainly the ELECTRE III/IV methods. The EDMs tried to gather as much as support from the scientific methods, so that the criteria weights were defined by two different methods as the Shannon's Entropy and the Saaty's AHP. In addition to these calculations, the equal weight calculations for the ELECTRE III were performed to increase the number of the experimental methods for a better analysis and investigation for this experimental research study and the future research studies (on the research, development, and deployment edge: the computer based intelligent decision making system and the autonomous decision making systems). All of these studies empowered the EDMs to express their ideas and made their mind up in a correct manner. The EDMs realized that the decision on the value of the indifference threshold $\left(q_{j}\right)$, the preference threshold $\left(p_{j}\right)$, and the veto threshold $\left(v_{j}\right)$ was very difficult and crucial. Henceforth the special attention should be given to the evaluation of these thresholds in the future research studies.

This experimental research study should be followed by the evaluation of the thresholds study. All of the thresholds should be reevaluated, wherever necessary and the final decisions should be taken according to these renewed calculations. In addition, the current experimental case study should be performed based on only the subjective criteria and only the objective criteria. This study will show how the final decisions are generally affected by the subjective factors. Moreover, the number of criteria and the combinations of criteria should be reorganized and a new study should be done or performed. Afterwards, the studies should be performed for the different project stages such as the development stages in the small hydropower plant industry.

These kinds of research studies most probably will help the investors, the institutions, organizations (international and domestic), and the governments to invest in the most appropriate investments in the real sectors that will help to use the resources (financial, manpower, and mind power) as efficiently and effectively as possible. Hence, the appropriateness, the suitability, the convenience, and the coherence of these kinds of investment decisions in the real sectors can surely affect, impact, and touch on the most positive way to the upper most objectives of humankind such as 
fighting against hunger and malnutrition, prevention of and fight against crime, keeping peace and security, respecting for justice and the rule of law, preserving human rights and freedom, improving health and wealth status.

\section{Conflict of Interests}

The author declares that there is no conflict of interests regarding the publication of this paper.

\section{Acknowledgment}

The author would like to deeply and sincerely thank Professor Dr. Bernard ROY for his help to make the author to understand clearly the distinction between ELECTRE III and ELECTRE IV methods and their respective results.

\section{References}

[1] H. Kemal Ozturk, A. Yilanci, and O. Atalay, "Past, present and future status of electricity in Turkey and the share of energy sources," Renewable and Sustainable Energy Reviews, vol. 11, no. 2, pp. 183-209, 2007.

[2] M. Balat, "Electricity consumption and economic growth in turkey: a case study," Energy Sources Part B: Economics, Planning and Policy, vol. 4, no. 2, pp. 155-165, 2009.

[3] G. Boluk and A. A. Koc, "Dynamics of energy consumption patterns in Turkey: its drivers and consequences," in Proceedings of the World Reneable Energy Congress on Sustainable Cities and Regions (SCR '11), pp. 3476-3483, Linkoping, Sweden, May 2011.

[4] Wikimedia Foundation, Wikipedia, Turkey, http://en.wikipedia .org/wiki/Turkey.

[5] G. Friedman, "Geopolitical Journey, Part 5: Turkey," Stratfor Global Intelligence, http://www.stratfor.com/weekly/20101122_ geopolitical_journey_part_5_turkey\#axzz3IfqoHhmN.

[6] Center for Strategic and International Studies (CSIS), "Search for Turkey," http://csis.org/.

[7] Wikimedia Foundation, "Geography of Turkey," Wikipedia, http://en.wikipedia.org/wiki/Geography_of_Turkey.

[8] Wikimedia Foundation, Wikipedia, Balkans, http://en.wikipedia.org/wiki/Balkans.

[9] Wikimedia Foundation, Inc., Wikipedia, Caucasus, 2014, http://en.wikipedia.org/wiki/Caucasus.

[10] Wikimedia Foundation, Wikipedia, Europe, http://en.wikipedia.org/wiki/Europe.

[11] Wikimedia Foundation, Wikipedia, MENA, Middle East and North Africa, http://en.wikipedia.org/wiki/MENA.

[12] Worldbank, "The data of the Gross Domestic Product (GDP) (current USD, 1961-2012)," 2013, http://www.worldbank.org/.

[13] Turkish Statistical Institute, "The data of the mid-year population estimations (1961-2012)," http://www.turkstat.gov.tr/.

[14] EMRA (Republic of Turkey Energy Market Regulatory Authority), "The data of the Turkish Electrical Energy 10year Generation Capacity Projection 2012-2021 Report," http://www.emra.gov.tr/, http://www.epdk.gov.tr/.

[15] TEIAS (Turkish Electricity Transmission Corporation), The data of the Turkish Electrical Energy 10 year Generation Capacity Projection 2012-2021 Report, http://www.teias.gov.tr/.

[16] EIA (US Energy Information Administration), http://www.eia .gov/tools/glossary/.
[17] USGS (U.S. Geological Survey), http://ga.water.usgs.gov/.

[18] ESHA (European Small Hydropower Association), Guide on How to Develop a Small Hydropower Plant, Brussels, Belgium, 2004.

[19] IWA (IWA Water Wiki), September 2013, http://www.iwawaterwiki.org/.

[20] Front Line, Protection Manual for Human Rights Defenders, Front Line The International Foundation For The Protection Of Human Rights Defenders, Dublin, Ireland, 2005.

[21] FreightWatch, FreightWatch International, 2013, http://www .freightwatchintl.com/.

[22] United Nations, 2013, http://www.un.org/en/terrorism/index .shtml.

[23] UNODC (United Nations Office on Drugs and Crime), 2013, http://www.unodc.org/.

[24] Wikimedia Foundation, Inc., Wikipedia, square kilometer, 2014, http://en.wikipedia.org/wiki/ Square_kilometre.

[25] Wikimedia Foundation, Wikipedia, cubic hectometer, 2014, http://en.wikipedia.org/wiki/Cubic_metre\#Multiples_and_submultiples.

[26] Wikimedia Foundation, Wikipedia, meter, 2014, http://en.wikipedia.org/wiki/Metre.

[27] Wikimedia Foundation, Wikipedia, cubic meter per second, 2014, http://en.wikipedia.org/wiki/Cubic_metre_per_second.

[28] Wikimedia Foundation, Wikipedia, gigawatt hour, 2014, http://en.wikipedia.org/wiki/Kilowatt_hour.

[29] Wikimedia Foundation, Wikipedia, million, 2014, http://en .wikipedia.org/wiki/Million.

[30] Wikimedia Foundation, Wikipedia, United States dollar, USD, US\$, U.S. dollar, American dollar, US Dollar, 2014, http://en.wikipedia.org/wiki/Million.

[31] S. A. Kartha, National Programme on Technology Enhanced Learning (NPTEL), Civil Engineering Courses, Advanced Hydraulics Course, 2014, http://nptel.ac.in/courses/105103021/.

[32] Pipe Flow Software, 2014, http://www.pipeflow.com/pipe-flowadvisor-software/channel-flow-calculator.

[33] C. Dragu, T. Sels, and R. Belmans, Small Hydro Power-State of the Art and Applications, ESAT-ELEN, Energy Institute, Leuven, Belgium, 2010.

[34] EREC (European Renewable Energy Council), REN21 Renewables 2012 Global Status Report, European Focus, Paris, France, 2012.

[35] ESHA (European Small Hydro Association), Guide on How to Refurbish Low Head Small Hydro Sites, ESHA, Brussels, Belgium, 2010.

[36] S. Mishra, S. K. Singal, and D. K. Khatod, "A review on electromechanical equipment applicable to small hydropower plants," International Journal of Energy Research, vol. 36, no. 5, pp. 553-571, 2012.

[37] T. V. Ramachandra and B. V. Shruthi, "Spatial mapping of renewable energy potential," Renewable and Sustainable Energy Reviews, vol. 11, no. 7, pp. 1460-1480, 2007.

[38] J. Figueira, V. Mousseau, and B. Roy, "Part III outranking methods," in Multiple Criteria Decision Analysis: State of the Art Surveys, J. Figueira, S. Greco, and M. Ehrgott, Eds., pp. 163-260, Springer, Boston, Mass, USA, 2005.

[39] W. C. Huang and C. H. Chen, "Using the ELECTRE II method to apply and analyze the differentiation theory," Proceedings of the Eastern Asia Society for Transportation Studies, vol. 5, pp. 2237-2249, 2005. 
[40] B. Roy, "The outranking approach and the foundations of ELECTRE methods," Theory and Decision, vol. 31, no. 1, pp. 4973, 1991.

[41] M. Bashiri and T. H. Hejazi, "An extension of multi-response optimization in MADM view," Journal of Applied Sciences, vol. 9, no. 9, pp. 1695-1702, 2009.

[42] J. Lair, T. Rissanen, and A. Sarja, Life Cycle Management of Concrete Infrastructures for Improved Sustainability Methods for Optimisation and Decision Making in Lifetime Management of Structures, European Community Competitive and Sustainable Growth Programme, 2004.

[43] X. Damaskos and G. Kalfakakou, "Application of ELECTRE III and DEA methods in the BPR of a bank branch network," Yugoslav Journal of Operations Research, vol. 15, no. 2, pp. 259276, 2005.

[44] J. R. Figueira, S. Greco, B. Roy, and R. Slowinski, ELECTRE Methods: Main Features and Recent Developments, vol. 298 of Cahier du Lamsadeá, Laboratoire d'Analyse et Modélisation de Systèmes pour l'Aide à la Décision, 2010.

[45] A. S. Milani, A. Shanian, and C. El-Lahham, "Using different ELECTRE methods in strategic planning in the presence of human behavioral resistance," Journal of Applied Mathematics and Decision Sciences, vol. 2006, Article ID 10936, 19 pages, 2006.

[46] M. Rogers and M. Bruen, "Choosing realistic values of indifference, preference and veto thresholds for use with environmental criteria within ELECTRE," European Journal of Operational Research, vol. 107, no. 3, pp. 542-551, 1998.

[47] J. Gong and J. Xu, "The integration of valued outranking relations in ELECTRE methods for ranking problem," World Journal of Modelling and Simulation, vol. 2, no. 1, pp. 3-14, 2006.

[48] L. F. A. M. Gomes, L. A. D. Rangel, and R. A. Moreira, "Using ELECTRE IV in the promotion of social and economic development: a case study in Rio De Janeiro," Foundations of Computing and Decision Sciences, vol. 34, no. 3, pp. 156-172, 2009.

[49] A. Shanian and O. Savadogo, "A non-compensatory compromised solution for material selection of bipolar plates for polymer electrolyte membrane fuel cell (PEMFC) using ELECTRE IV," Electrochimica Acta, vol. 51, no. 25, pp. 5307-5315, 2006.

[50] H. Y. Tsai and T. X. Bui, Implementing a multiple criteria model base in Co-op with a graphical user interface generator [M.S. thesis], Naval Postgraduate School, Monterey, Calif, USA, 1993.

[51] G. H. Tzeng, T. Y. Chen, and J. C. Wang, "A weight-assessing method with habitual domains," European Journal of Operational Research, vol. 110, no. 2, pp. 342-367, 1998.

[52] M. Shinohara, C. Miyake, and K. Ohsawa, "Why not use the entropy method for weight estimation?" in Proceedings of the 6th International Symposium on the Analytic Hierarchy Process (ISAHP '01), Berne, Switzerland, August 2001.

[53] F. H. Lotfi and R. Fallahnejad, "Imprecise shannon's entropy and multi attribute decision making," Entropy, vol. 12, no. 1, pp. 5362, 2010.

[54] L. Abdullah and A. Otheman, "A new entropy weight for subcriteria in interval type-2 fuzzy TOPSIS and its application," International Journal of Intelligent Systems and Applications, vol. 5, no. 2, pp. 25-33, 2013.

[55] T. Akyene, "Cell phone evaluation base on entropy and TOPSIS," Interdisciplinary Journal of Research in Business, vol. 1, no. 12, pp. 9-15, 2012.
[56] Z.-H. Zou, Y. Yun, and J.-N. Sun, "Entropy method for determination of weight of evaluating indicators in fuzzy synthetic evaluation for water quality assessment," Journal of Environmental Sciences, vol. 18, no. 5, pp. 1020-1023, 2006.

[57] C. E. Shannon, "A mathematical theory of communication," The Bell System Technical Journal, vol. 27, pp. 379-423, 1948.

[58] T. L. Saaty, The Analytic Hierarchy Process, McGraw-Hill, New York, NY, USA, 1980.

[59] T. L. Saaty, "How to make a decision: the analytic hierarchy process," European Journal of Operational Research, vol. 48, pp. 9-26, 1990.

[60] T. L. Saaty, "Decision making with the analytic hierarchy process," International Journal of Services Sciences, vol. 1, no. 1, pp. 83-98, 2008.

[61] Wikimedia Foundation, Wikipedia, Watt, November 2014, http://en.wikipedia.org/wiki/Watt.

[62] J. Eliasson and G. Ludvigsson, "Load factor of hydropower plants and its importance in planning and design," in Proceedings of the 11th International Seminar on Hydro Power Plants, Hydros Future in Changing Markets, University of Technology, Vienna, Austria, November 2000.

[63] ESHA (European Small Hydropower Association), Brochure on Environmental Integration of Small Hydropower Plants, Brussels, Belgium, 2005.

[64] M. F. Scheier and C. S. Carver, "On the power of positive thinking: the benefits of being optimistic," Current Directions in Psychological Science, vol. 2, no. 1, pp. 26-30, 1993.

[65] A. K. MacLeod and R. Moore, "Positive thinking revisited: positive cognitions, well-being and mental health," Clinical Psychology \& Psychotherapy, vol. 7, no. 1, pp. 2-10, 2000.

[66] D. E. Goodhart, "The effects of positive and negative thinking on performance in an achievement situation," Journal of Personality and Social Psychology, vol. 51, no. 1, pp. 117-124, 1986.

[67] D. J. Siegel, The Developing Mind, How Relationships and the Brain Interact to Shape Who We Are, The Guilford Press, New York, NY, USA, 2012.

[68] T. Williamson, "Is knowing a state of mind?" Mind, vol. 104, no. 415, pp. 533-565, 1995.

[69] R. Likert, "A technique for the measurement of attitudes," Archives of Psychology, vol. 22, no. 140, 1932.

[70] G. A. Miller, "The magical number seven, plus or minus two: some limits on our capacity for processing information," Psychological Review, vol. 63, no. 2, pp. 81-97, 1956.

[71] R. M. Shiffrin and R. M. Nosofsky, "Seven plus or minus two: a commentary on capacity limitations," Psychological Review, vol. 101, no. 2, pp. 357-361, 1994.

[72] B. Rohrmann, "Verbal qualifiers for rating scales: sociolinguistic considerations and psychometric data," Project Report, University of Melbourne, Melbourne, Australia, 2007, http:// www.rohrmannresearch.net/pdfs/rohrmann-vqs-report.pdf.

[73] Ermatita, S. Hartati, R. Wardoyo, and A. Harjoko, "ELECTREentropy method in group decision support system modelto gene mutation detection," International Journal of Advanced Research in Artificial Intelligence, vol. 1, no. 1, pp. 58-63, 2012.

[74] P. le Gauffre, R. Baur, K. Laffrechine, and M. Miramond, "D7 report: survey of multi-criteria techniques and selection of relevant procedures," CARE-W, EU project under the 5th Framework Program, contract no: EVK1-CT-2000-00053, 2002.

[75] J. C. Leyva-López and E. Fernández-González, "A new method for group decision support based on ELECTRE III methodology," European Journal of Operational Research, vol. 148, no. 1, pp. 14-27, 2003. 
[76] V. Mousseau, J. Figueira, and J.-P. Naux, "Using assignment examples to infer weights for ELECTRE TRI method: some experimental results," European Journal of Operational Research, vol. 130, no. 2, pp. 263-275, 2001.

[77] V. Mousseau and L. Dias, "Valued outranking relations in ELECTRE providing manageable disaggregation procedures," European Journal of Operational Research, vol. 156, no. 2, pp. 467-482, 2004.

[78] M. F. Norese, "ELECTRE III as a support for participatory decision-making on the localisation of waste-treatment plants," Land Use Policy, vol. 23, no. 1, pp. 76-85, 2006.

[79] P. S. Nagpaul, Guide to Advanced Data Analysis Using IDAMS Software, 2014, http://www.unesco.org/webworld/idams/ advguide/TOC.htm.

[80] United Nations Educational, and Scientific and Cultural Organization (UNESCO), "Communication and Information, Free and Open Source Software (FOSS), Internationally Developed Data Analysis and Management Software (IDAMS)," 2014, http://www.unesco.org/new/en/communication-andinformation/access-to-knowledge/free-and-open-source-software-foss/idams/.

[81] G. del Bigio, "The UNESCO IDAMS software packages: internationally developed data analysis and management software," Information Technology for Development, vol. 4, no. 1, pp. 73-74, 1989.

[82] Wikimedia Foundation, Inc., Wikipedia, IDAMS, 2014, http:// en.wikipedia.org/wiki/IDAMS. 


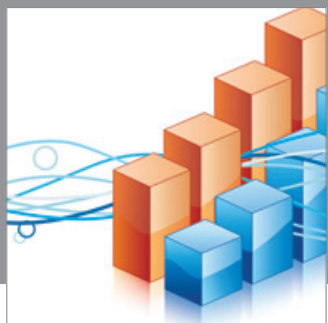

Advances in

Operations Research

mansans

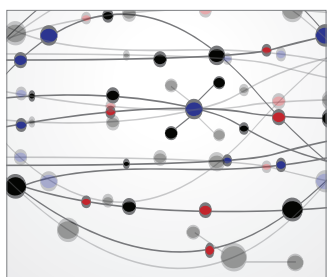

The Scientific World Journal
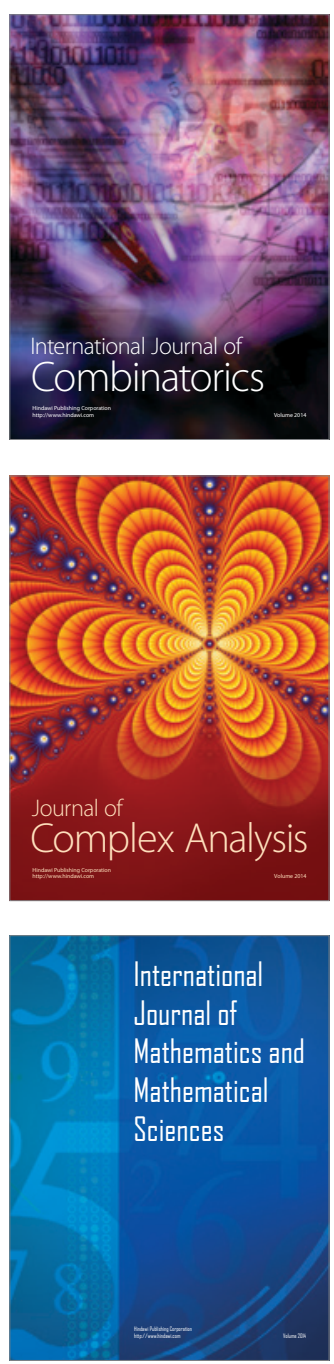
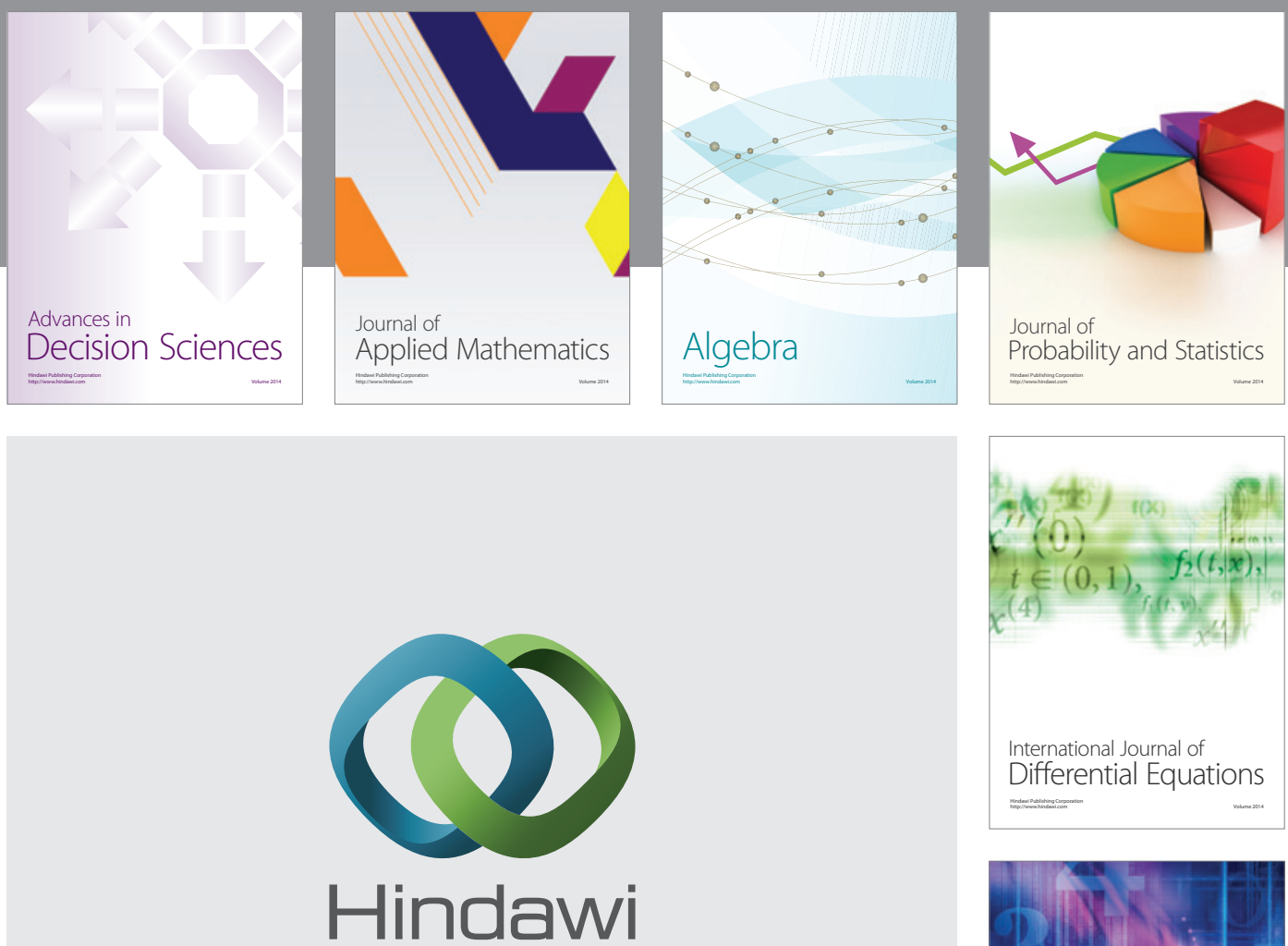

Submit your manuscripts at http://www.hindawi.com
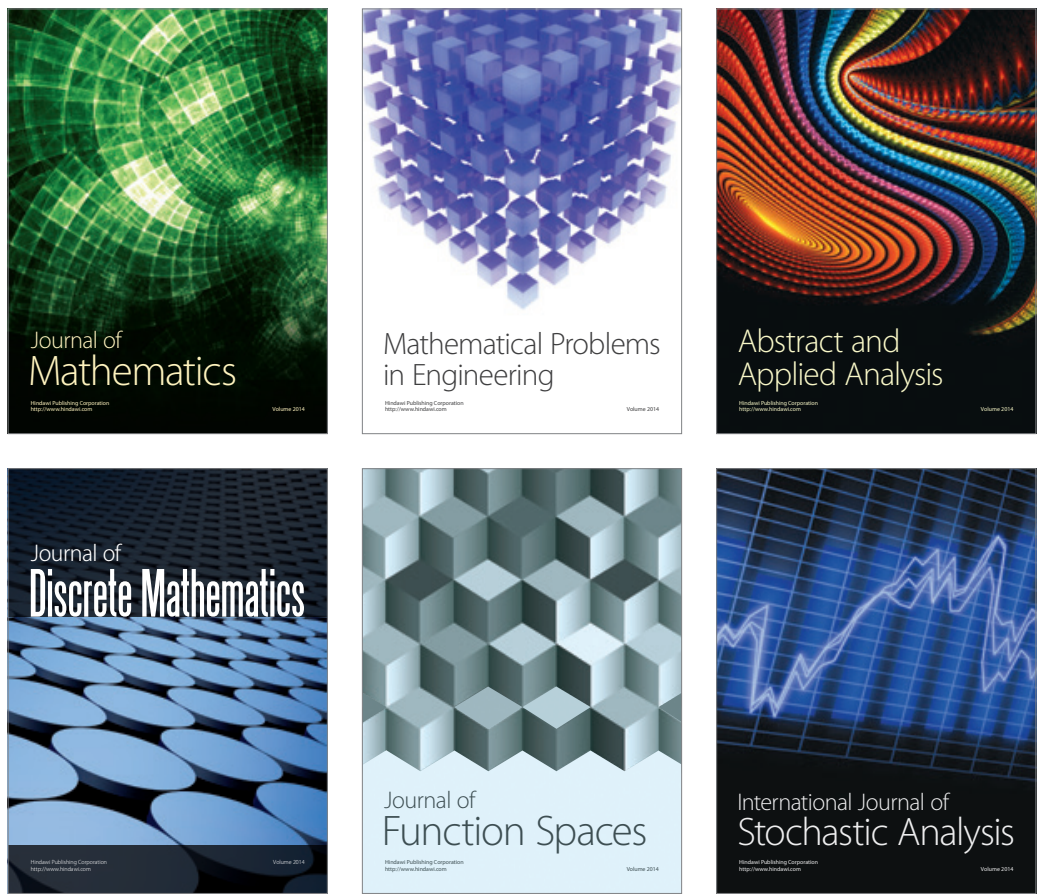

Journal of

Function Spaces

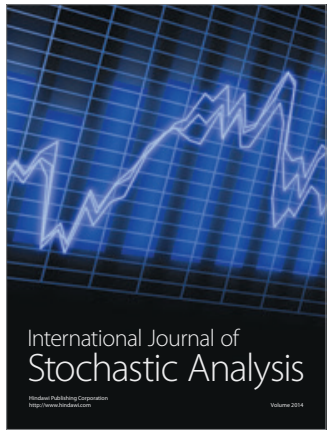

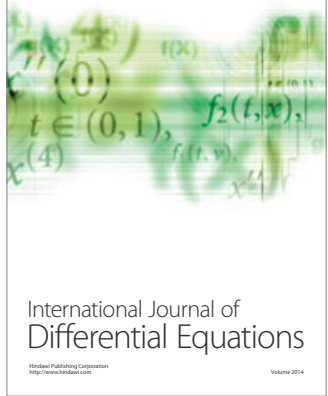
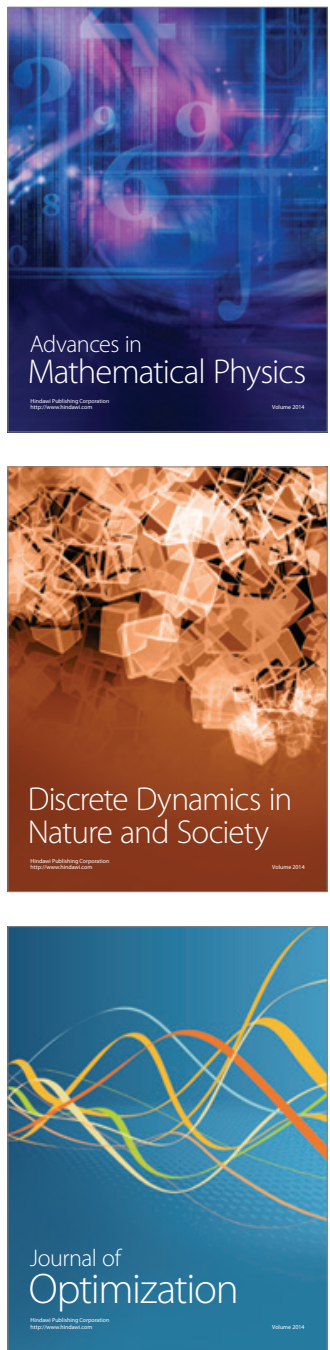